\title{
Clinical Pharmacokinetics of Penicillins, Cephalosporins and Aminoglycosides in the Neonate: A Review
}

\section{Gian Maria Pacifici}

Section of Pharmacology, Department of Neurosciences, Medical School, University of Pisa, Via Roma 55, 56126 Pisa, Italy; E-Mail: pacifici@biomed.unipi.it; Tel.: +39-050-22-18-721; Fax: +39-050-22-18-717

Received: 2 July 2010; in revised form: 22 July 2010 / Accepted: 3 August 2010 /

Published: 12 August 2010

\begin{abstract}
Bacterial infections are common in the neonates and are a major cause of morbidity and mortality. Sixty percent of preterm infants admitted to neonatal intensive care units received at least one antibiotic during the first week of life. Penicillins, aminoglycosides and cephalosporins comprised 53, 43 and 16\%, respectively. Kinetic parameters such as the half-life $\left(\mathrm{t}_{1 / 2}\right)$, clearance $(\mathrm{Cl})$, and volume of distribution $(\mathrm{Vd})$ change with development, so the kinetics of penicillins, cephalosporins and aminoglycosides need to be studied in order to optimise therapy with these drugs. The aim of this study is to review the pharmacokinetics of penicillins, cephalosporins and aminoglycosides in the neonate in a single article in order to provide a critical analysis of the literature and thus provide a useful tool in the hands of physicians. The bibliographic search was performed electronically using PubMed, as the search engine, until February $2^{\text {nd }}, 2010$. Medline search terms were as follows: pharmacokinetics AND (penicillins OR cephalosporins OR aminoglycosides) AND infant, newborn, limiting to humans. Penicillins, cephalosporins and aminoglycosides are fairly water soluble and are mainly eliminated by the kidneys. The maturation of the kidneys governs the pharmacokinetics of penicillins, cephalosporins and aminoglycosides in the neonate. The renal excretory function is reduced in preterms compared to term infants and $\mathrm{Cl}$ of these drugs is reduced in premature infants. Gestational and postnatal ages are important factors in the maturation of the neonate and, as these ages proceed, $\mathrm{Cl}$ of penicillins, cephalosporins and aminoglycosides increases. $\mathrm{Cl}$ and $\mathrm{t}_{1 / 2}$ are influenced by development and this must be taken into consideration when planning a dosage regimen with these drugs. More pharmacokinetic studies are required to ensure that the dose recommended for the treatment of sepsis in the neonate is evidence based.
\end{abstract}


Keywords: penicillins; cephalosporins; aminoglycosides; pharmacokinetics; neonate

\section{Introduction}

Over $60 \%$ of the preterm neonates admitted to the neonatal intensive care units received at least one antibiotic during the first week of life, of which penicillins, aminoglycosides and cephalosporins comprised 53, 43 and $16 \%$, respectively [1].

Sepsis in neonates has an estimated mortality of $10-20 \%$, with sequelae in $25-30 \%$ of the infants who survived [2]. Immaturity of humoral, cellular and myeloid cell line immunity places the neonate at higher risk for infection than older infants and children [3]. The physiological conditions of neonates are different from those of adults. Neonates have a larger extracellular fluid volume [4] they also have immature liver and kidney functions as well as higher plasma concentrations of bilirubin and nonesterified fatty acids [5]. The water content is larger in preterm than in term infants [6] and penicillins, cephalosporins and aminoglycosides are fairly water soluble and are distributed in larger volume in preterm than term infants. These antibiotics are mainly eliminated by the kidneys and their renal glomerular filtration and tubular secretion are reduced in the neonate [7]. The reduced renal excretory function affects the disposition of penicillins, cephalosporins and aminoglycosides and their clearance (Cl) is reduced in newborn infants compared to children. The volume of distribution (Vd) of penicillins, cephalosporins and aminoglycosides tends to be larger in the neonate than in the adult because of the larger water body content in the neonate.

The extensive use of antibiotics in the neonate requires that their pharmacokinetics should be studied. The aim of this article is to provide the review of the literature on the pharmacokinetics of penicillins, cephalosporins and aminoglycosides in the infant in a single article in order to provide a tool that can be useful in the hands of physicians. This note also serves as an updated source of the literature on the pharmacokinetics of the penicillins, cephalosporins and aminoglycosides in the newborn infant.

\section{Bibliographic Search}

The bibliographic search was performed electronically using PubMed, as the search engine, until February $2^{\text {nd }}, 2010$. Medline search terms were as follows: pharmacokinetics AND (penicillins OR cephalosporins OR aminoglycosides) AND infant, newborn, limiting to humans. In addition, the book Neofax: a Manual of Drugs Used in the Neonatal Care by Young and Mangum [8] was consulted. The finding of the bibliographic search gave rise to 94 original articles, 11 review articles and two book chapters. The publication years of this subject matter ranged from 1961 to 2010. The references were "copied" from PubMed, "pasted" to the manuscript and edited according the style of the journal Pharmaceuticals.

\section{Results}

Tables 1, 3 and 5 report the number of retrieved studies and the number of drugs evaluated for penicillins, cephalosporins and aminoglycosides, respectively. The pharmacokinetic parameters are 
clustered in three tables. Table 2 summarizes the pharmacokinetic results of penicillins, Table 4 shows the data relative to cephalosporins and the data relative to aminoglycosides are given in Table 6 . The p-value refers to the data in the two rows above of Tables 2,4 and 6.

\section{Penicillins}

Table 1. Number of retrieved studies and number of drugs evaluated.

\begin{tabular}{|l|c|c|c|}
\hline \multicolumn{1}{|c|}{ Drugs } & $\begin{array}{c}\text { Number of } \\
\text { retrieved studies }\end{array}$ & $\begin{array}{c}\text { Number of drugs } \\
\text { evaluated }\end{array}$ & $\begin{array}{c}\text { Overall number of } \\
\text { neonates studied }\end{array}$ \\
\hline Benzyl penicillin & 3 & 1 & 67 \\
Ampicillin & 3 & 1 & 69 \\
Amoxicillin & 5 & 1 & 233 \\
Flucloxacillin & 3 & 1 & 75 \\
Azlocillin & 2 & 1 & 81 \\
Mezlocillin & 2 & 1 & 100 \\
Ticarcillin & 3 & 1 & 90 \\
\hline Total & 21 & 7 & 715 \\
\hline
\end{tabular}

\subsection{Benzyl penicillin (penicillin G; see Table 2)}

McKraken et al. [9], Metsvaht et al. [10] and Muller et al. [11] reported a study on the pharmacokinetics of benzyl penicillin in the neonate. Little is known about the gestational age; the half-life $\left(\mathrm{t}_{1 / 2}\right)$ decreased from $3.2 \mathrm{~h}$ in low birth weight in the first week of life to 1.4 in week 3 [9]. In very low birth weight, $\mathrm{t}_{1 / 2}$ is $4.6 \mathrm{~h}$. The $\mathrm{Cl}$ ranged from 1.2 to $1.7 \mathrm{~mL} / \mathrm{min} / \mathrm{kg}$, $\mathrm{Vd}$ ranged between 0.41 and $0.65 \mathrm{~L} / \mathrm{kg}$, and $\mathrm{t} 1 / 2$ ranged from 1.4 to 4.6 . The daily dose of benzyl penicillin ranged from $10-30 \mathrm{mg} / \mathrm{kg}$ [9] and from 15 to $30 \mathrm{mg} / \mathrm{kg}$ twice a day [10]. Young and Mangum [8] suggested a dose of 45 to $60 \mathrm{mg} / \mathrm{kg}$ for treatment of meningitis and a dose of 15 to $30 \mathrm{mg} / \mathrm{kg}$ for the treatment of bacteraemia. When the postmenstrual age ranged from $\leq 29$ to $\leq 44$ weeks, benzyl penicillin should be administered every 8 or $12 \mathrm{~h}$, when the postmenstrual age $\geq 45$ weeks the drug should be administered every $6 \mathrm{~h}$.

\subsection{Broad spectrum penicillins}

\subsubsection{Ampicillin (see Table 2)}

Three articles on the pharmacokinetics of ampicillin in the neonates have been reported [12-14]. In infants with a gestational age $>37$ weeks, $\mathrm{t}_{1 / 2}$ ranged from 2.2 to $3.9 \mathrm{~h}$ whereas in infants with a gestational age $<37$ weeks $\mathrm{t}_{1 / 2}$ was $4.0 \mathrm{~h}$. No data are available relative to $\mathrm{Cl}$ and $\mathrm{Vd}$. Axline et al. [15] studied the effect of postnatal age on $t_{1 / 2}$ of ampicillin. When the postnatal age ranged from 2 to 7 , from 8 to 14, from 15 to 30 and from 61 to 68 days $\mathrm{t}_{1 / 2}$ was 4.0, 2.8, 1.7 and $1.6 \mathrm{~h}$, respectively.

Young and Mangum [8] suggested a dose of 25 to $50 \mathrm{mg} / \mathrm{kg}$ and $100 \mathrm{mg} / \mathrm{kg}$ for the treatment of meningitis. When the postmenstrual age ranged from $\leq 29$ to $\leq 44$ weeks ampicillin should be administered every 8 or $12 \mathrm{~h}$. When the postmenstrual age $\geq 45$, ampicillin should be administered every $6 \mathrm{~h}$. 
Table 2. Pharmacokinetic parameters of benzylpenicillin. Figures are the mean or range.

\begin{tabular}{|c|c|c|c|c|c|c|c|}
\hline $\begin{array}{l}\text { Gestational } \\
\text { age (weeks) }\end{array}$ & $\begin{array}{l}\text { Daily dose } \\
\text { (mg/kg) }\end{array}$ & $\begin{array}{l}\text { Cl } \\
(\mathrm{mL} / \mathrm{min} / \mathrm{kg})\end{array}$ & $\begin{array}{l}\text { Vd } \\
\text { (L/kg) }\end{array}$ & $\mathbf{t}_{1 / 2}(\mathrm{~h})$ & $\begin{array}{l}\text { Peak } \\
\text { conc. } \\
(\mu \mathrm{g} / \mathrm{mL})\end{array}$ & $\begin{array}{l}\text { Trough } \\
\text { conc. } \\
(\mu g / m L)\end{array}$ & Ref. \\
\hline \multicolumn{8}{|c|}{ Benzyl (penicillin G) } \\
\hline na & $10-30 \mathrm{IM}$ & na & na & 3.2 & $22-36$ & na & \multirow{2}{*}{ [9] } \\
\hline na & $10 \mathrm{IM}$ & na & na & 1.4 & na & na & \\
\hline$<28$ & $30 \times 2$ & 1.2 & 0.41 & 3.8 & 146 & 7 & \multirow{2}{*}[10]{} \\
\hline$<28$ & $15 \times 2$ & 1.5 & 0.65 & 4.6 & 59 & 3 & \\
\hline$<32$ & $30 \times 2$ & 1.7 & 0.50 & 3.9 & na & na & [11] \\
\hline \multicolumn{8}{|l|}{ Ampicillin } \\
\hline$>37$ & $\begin{array}{l}50-100 \\
\text { infusion }\end{array}$ & na & na & 2.2 & na & na & {$[12]$} \\
\hline$>37$ & $50-100 \times 2$ IM & na & na & 3.9 & $36-257$ & na & \multirow{2}{*}{ [14] } \\
\hline$<37$ & $50-100 \times 2 \mathrm{IM}$ & 5.5 & na & 5.5 & $78-293$ & na & \\
\hline na & $50 \times 3 \mathrm{IM}$ & na & na & 1.6 & 58 & na & {$[15]$} \\
\hline \multicolumn{8}{|l|}{ Amoxicillin } \\
\hline$<32$ & $25 \times 2$ & 1.0 & 0.67 & 6.7 & 54 & 16 & [17] \\
\hline$\leq 32$ & $50 \times 2$ & 1.3 & 0.68 & na & 74 & na & {$[16]$} \\
\hline $25-42$ & 30 & 1.6 & 0.65 & \begin{tabular}{|l|}
5.2 \\
\end{tabular} & 101 & 21 & $\begin{array}{l}\text { L } \\
{[18]}\end{array}$ \\
\hline $26-41$ & $50-100$ & 3.0 & 0.66 & 3.0 & na & na & [20] \\
\hline$>37$ & 50 & na & na & na & 38 & 13 & \multirow{2}{*}{ [21] } \\
\hline$<37$ & 50 & na & na & na & 59 & 19 & \\
\hline \multicolumn{8}{|c|}{ Flucloxacillin } \\
\hline $26-42$ & $25-50 \times 3$ & 3.0 & 0.54 & 2.6 & $38-114$ & na & [22] \\
\hline $33-41$ & 50 & 0.7 & 0.28 & 4.6 & na & na & [23] \\
\hline na & $30 \times 3$ & $2.0^{*}$ & $0.45^{*}$ & $2.6^{*}$ & $15-70^{*}$ & na & [19] \\
\hline \multicolumn{8}{|l|}{ Azlocillin } \\
\hline$<37$ & $\begin{array}{l}50 \times 2 \mathrm{IM} \text { or } \\
\mathrm{IV}\end{array}$ & na & 0.34 & 4.4 & 122 & 20 & \multirow{3}{*}[24]{} \\
\hline $37-42$ & $50 \times 2 \mathrm{IM} / \mathrm{IV}$ & na & 0.30 & 2.6 & 128 & 27 & \\
\hline $37-42$ & $\begin{array}{l}100 \times 2 \mathrm{IM} \text { or } \\
\mathrm{IV}\end{array}$ & na & 0.30 & 2.6 & 260 & 17 & \\
\hline$<37$ & 50 & 3.7 & 0.33 & 2.5 & na & na & \multirow{2}{*}{ [25] } \\
\hline $37-42$ & 50 & 4.9 & 0.32 & 2.6 & na & na & \\
\hline \multicolumn{8}{|l|}{ Mezlocillin } \\
\hline $26-40$ & 75 IV or IM & 1.3 & 0.38 & 3.7 & 231 & 43 & {$[26]$} \\
\hline$<38$ & See text & $\begin{array}{l}9.3(\mathrm{~mL} / \mathrm{min} \text { per } \\
\left.1.73 \mathrm{~m}^{2}\right)\end{array}$ & 0.34 & 4.5 & 252 & 72 & \multirow[t]{2}{*}{ [27] } \\
\hline $38-42$ & & $\begin{array}{l}12.3(\mathrm{~mL} / \mathrm{min} \\
\left.\text { per } 1.73 \mathrm{~m}^{2}\right)\end{array}$ & 0.37 & 3.0 & 272 & 34 & \\
\hline \multicolumn{8}{|l|}{ Ticarcillin } \\
\hline 31 & $75 \times 2$ & na & na & 4.5 & 183 & 43 & {$[28]$} \\
\hline $34-36$ & $83 \times 3$ & na & 0.34 & 4.2 & 279 & 64 & \multirow[t]{2}{*}{ [29] } \\
\hline$>37$ & $100 \times 3$ & na & 0.27 & 2.7 & 402 & 56 & \\
\hline 30 & $75 \times 2$ & 0.78 & 0.26 & 4.2 & 976 & 42 & {$[30]$} \\
\hline
\end{tabular}




\subsubsection{Amoxicillin (see Table 2)}

When amoxicillin was administered in association with gentamicin there was a decrease of amoxicillin $\mathrm{Cl}$ of $25 \%$ [16]. Charles et al. [16] found a prolongation of $\mathrm{t}_{1 / 2}$ and an increase of Vd when amoxicillin was co-administered with gentamicin in preterm infants. Huisman-de Boer et al. [17] and Pullen et al. [18] studied the pharmacokinetics of amoxicillin in neonates. Huisman-de Boer et al. [17] recommend a dose of $15 \mathrm{mg} / \mathrm{kg}$ every $8 \mathrm{~h}$ for neonates with gestational age $<34$ weeks and $20 \mathrm{mg} / \mathrm{kg}$ every $8 \mathrm{~h}$ when the gestational age $>34$ weeks. Pullen et al. [18] suggested that preterm infants with gestational age $<32$ weeks in the first week of life receive a maximum amoxicillin dose of $25 \mathrm{mg} / \mathrm{kg}$ every $12 \mathrm{~h}$. Cardiopulmonary bypass decreased the mean plasma concentration by $36 \%$, from 73 to $47 \mu \mathrm{g} / \mathrm{mL}$ [19]. $\mathrm{t}_{1 / 2}$ ranged from 3.0 to $6.7, \mathrm{Vd}$ ranged from 0.65 to $0.68 \mathrm{~L} / \mathrm{kg}$ and $\mathrm{Cl}$ ranged from 1.0 to $3.0 \mathrm{~mL} / \mathrm{min} / \mathrm{kg}$. In the studies by Huisman-de Boer et al. [17] and Pullen et al. [18] $\mathrm{Cl}$ and Vd were found to increase with gestational age. Preterm infants have a longer $t_{1 / 2}(6.7 \mathrm{~h})$ than term neonates $(3.0 \mathrm{~h})$.

\subsection{Penicillinase-resistant penicillins}

\subsubsection{Flucloxacillin (see Table 2)}

The dose of flucloxacillin ranged from $30 \mathrm{mg} / \mathrm{kg}$ thrice daily [19] to $50 \mathrm{mg} / \mathrm{kg}$ every $8 \mathrm{~h} \mathrm{[22].}$ Pullen et al. [22] observed that a dose of $50 \mathrm{mg} / \mathrm{kg}$ thrice daily did not result in effective plasma concentrations for the treatment of Staphylococcus aureus. They suggested using $25 \mathrm{mg} / \mathrm{kg}$ every $6 \mathrm{~h}$ for all neonates. Cardiopulmonary bypass decreased the plasma concentration of flucloxacillin by $40 \%$ [19]. $\mathrm{Cl}$ ranged from 0.7 to $3.0 \mathrm{~mL} / \mathrm{min} / \mathrm{kg}, \mathrm{Vd}$ ranged from 0.28 to $0.54 \mathrm{~L} / \mathrm{kg}$ and $\mathrm{t}_{1 / 2}$ ranged from 2.6 to $4.6 \mathrm{~h}$. A small study of nine neonates suggested that $\mathrm{t}_{1 / 2}$ was related to gestational age [23].

\subsection{Antipseudomonal penicillins}

\subsubsection{Alzocillin (see Table 2)}

Sitka et al. [24] suggested a dose of $50 \mathrm{mg} / \mathrm{kg}$ of azlocillin for preterm neonates in the first 7 days of life and $100 \mathrm{mg} / \mathrm{kg}$ every $12 \mathrm{~h}$ in full term neonates in the first 7 days of life. Another study [25] did not find difference in $\mathrm{t}_{1 / 2}$ in preterm and term infants. $\mathrm{Cl}$ ranged from 3.7 to $4.9 \mathrm{~mL} / \mathrm{min}, \mathrm{Vd}$ ranged from 0.30 to $0.34 \mathrm{~L} / \mathrm{kg}$ and $\mathrm{t}_{1 / 2}$ ranged from 2.5 to $4.4 \mathrm{~h}$.

\subsubsection{Mezlocillin (see Table 2)}

The mezlocillin serum concentrations were influenced by the co-administration with an aminoglycoside [26]. $\mathrm{Cl}$ of mezlocillin increased with gestational age and was negatively influenced by aminoglycoside co-administration. There was no relationship between $\mathrm{Vd}$ and body weight. Janicke et al. [26] suggested a dose of $75 \mathrm{mg} / \mathrm{kg}$ every 8-12 h. Another study [27] recommended a dose of $75 \mathrm{mg} / \mathrm{kg}$ every $12 \mathrm{~h}$ to preterm infants in the first week of life and $75 \mathrm{mg} / \mathrm{kg}$ every $8 \mathrm{~h}$ for preterm and term infants with postnatal age $>7$. In one study, $\mathrm{Cl}$ was $1.3 \mathrm{~mL} / \mathrm{min} / \mathrm{kg}$ [26] and in 
another study [27], $\mathrm{Cl}$ ranged from 9.3 to $12.3 \mathrm{~mL} / \mathrm{min}$ per $1.73 \mathrm{~m}^{2}$. Vd ranged from 0.34 to $0.38 \mathrm{~L} / \mathrm{kg}$ and $\mathrm{t}_{1 / 2}$ ranged from 3.0 to $4.5 \mathrm{~h}$.

\subsubsection{Ticarcillin (see Table 2)}

Ticarcillin was administered in combination with clavulanic acid [29;30]. The ratios of ticarcillin:clavulanic acid was 15:1 [28] and 30:1 [29]. Another study used a 25:1 ratio of

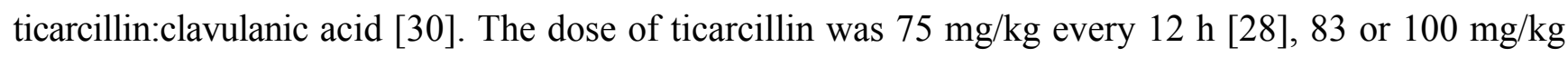
thrice daily [29] and $75 \mathrm{mg} / \mathrm{kg}$ twice a day [30]. Vd ranged from 0.26 to $0.34 \mathrm{~L} / \mathrm{kg}$ and $\mathrm{t}_{1 / 2}$ ranged between 2.7 and $4.5 \mathrm{~h}$. Young and Mangum [8] suggested 75 or $100 \mathrm{mg} / \mathrm{kg}$ every 8 or $12 \mathrm{~h}$ up to a postmenstrual age of $\leq 44$ weeks and every $6 \mathrm{~h}$ when the postmenstrual age was $>45$ weeks.

The findings more relevant from a clinical point of view have reported hereafter. Penicillins are rapidly eliminated mostly by renal route and their toxicity is limited. The kinetic parameters, including the peak concentration, range over a wide interval. Penicillins are mostly used to treat infections sustained by Gram-positive bacteria and are a key components in neonatal intensive care units. Gestational and postnatal ages influence $\mathrm{Cl}$ and $\mathrm{t}_{1 / 2}$ of penicillins. The minimal toxicity associated with penicillins in comparison with other antibiotics such as aminoglycosides and second- and thirdgeneration cephalosporins is probably one of the reasons why there have been few studies on the kinetics of penicillin in the neonate. There is a considerable dose variation for both benzylpenicillin and flucloxacillin and, to a lesser extent, for ampicillin and amoxicillin.

\section{Cephalosporins}

Table 3. Number of retrieved studies and number of drugs evaluated.

\begin{tabular}{|l|c|c|c|}
\hline \multicolumn{1}{|c|}{ Drug } & $\begin{array}{c}\text { Number of } \\
\text { retrieved studies }\end{array}$ & $\begin{array}{c}\text { Number of drugs } \\
\text { evaluated }\end{array}$ & $\begin{array}{c}\text { Overall number of } \\
\text { neonates studied }\end{array}$ \\
\hline Cefazolin & 1 & 1 & 11 \\
Cefoxitin & 1 & 1 & 15 \\
Cefuroxime & 1 & 1 & 104 \\
Cefotaxime & 7 & 1 & 130 \\
Ceftazidime & 6 & 1 & 283 \\
Ceftriazone & 5 & 1 & 199 \\
Cefoperazone & 4 & 1 & 75 \\
Ceftizoxime & 2 & 1 & 102 \\
Cefepime & 3 & 1 & 93 \\
\hline Total & 30 & 9 & 1012 \\
\hline
\end{tabular}

\subsection{First Generation Cephalosporins}

\subsubsection{Cefazolin (see Table 4)}

Deguchi et al. [31] studied the pharmacokinetics of cefazolin; there was a marked interindividual variability in $\mathrm{Vd}$ that ranged from 0.21 to $0.37 \mathrm{~L} / \mathrm{kg}$. The unbound fraction of cefazolin in neonatal plasma ranged from 0.22 to 0.83 . There was a correlation $(r=0.936 ; p<0.001)$ between cefazolin $\mathrm{Vd}$ and the plasma unbound fraction of this drug. 
Young and Mangum [8] suggested administering $25 \mathrm{mg} / \mathrm{kg}$ cefazolin every 8 to $12 \mathrm{~h}$ when the postmenstrual age ranged from $\leq 29$ to $\leq 44$ weeks. When the postmenstrual age is $\geq 45$ weeks the interval between doses should be $6 \mathrm{~h}$.

Table 4. Pharmacokinetic parameters of cephalosporins. Figures are the mean or range.

\begin{tabular}{|c|c|c|c|c|c|c|c|}
\hline $\begin{array}{l}\text { Gestational } \\
\text { age (weeks) }\end{array}$ & $\begin{array}{l}\text { Daily dose } \\
\text { (mg/kg) }\end{array}$ & $\begin{array}{l}\text { Cl } \\
(\mathrm{mL} / \mathrm{min} / \mathrm{kg})\end{array}$ & Vd (L/kg) & $\mathbf{t}_{1 / 2}(\mathrm{~h})$ & $\begin{array}{l}\text { Peak } \\
\text { conc. } \\
(\mu \mathrm{g} / \mathrm{mL})\end{array}$ & $\begin{array}{l}\text { Trough } \\
\text { conc. } \\
(\mu g / m L)\end{array}$ & Ref. \\
\hline \multicolumn{8}{|l|}{ Cefazolin } \\
\hline 35 & 30 & 0.80 & 0.28 & na & na & na & [31] \\
\hline \multicolumn{8}{|l|}{ Cefoxitin } \\
\hline 36 & $30 \times 3$ & 4.5 & 0.50 & 1.4 & 69 & na & [32] \\
\hline \multicolumn{8}{|l|}{ Cefuroxime } \\
\hline na & $10 \times 3$ & na & na & 4.6 & 24 & 6.4 & [33] \\
\hline \multicolumn{8}{|l|}{ Cefotaxime } \\
\hline \multirow{2}{*}{$\begin{array}{l}\text { Preterm } \\
\text { Term }\end{array}$} & \multirow[t]{2}{*}{ Note A } & $1.37(\mathrm{~mL} / \mathrm{min})$ & 0.61 & 5.7 & na & na & [34] \\
\hline & & $4.45(\mathrm{~mL} / \mathrm{min})$ & 0.69 & 2.0 & --- & --- & \\
\hline \multirow{2}{*}{\begin{tabular}{|l|}
$\mathrm{p}$ \\
Preterm
\end{tabular}} & --- & $<0.05$ & NS & 3.1 & --- & --- & \\
\hline & 50 & $\begin{array}{l}23.0(\mathrm{~mL} / \mathrm{min} / \\
\left.1.73 \mathrm{~m}^{2}\right)\end{array}$ & 0.51 & 4.6 & 116 & 34 & \multirow[t]{3}{*}{ [35] } \\
\hline Term & 50 & $\begin{array}{l}49.3(\mathrm{~mL} / \mathrm{min} / \\
\left.1.73 \mathrm{~m}^{2}\right) \\
\end{array}$ & 0.44 & 3.4 & 133 & 38 & \\
\hline $\mathrm{P}$ & --- & $<0.001$ & $<<0.01$ & $<0.01$ & NS & NS & \\
\hline 30 & $50 \times 2$ & 0.50 & 0.42 & 4.6 & na & na & \multirow[t]{3}{*}{ [37] } \\
\hline 38 & $50 \times 2$ & 1.07 & 0.28 & 4.0 & na & na & \\
\hline $\mathrm{p}$ & --- & NS & $<0.05$ & NS & --- & --- & \\
\hline$<32$ & $25 \times 2$ & 1.08 & 0.34 & 3.5 & 74 & 11 & \multirow{3}{*}{ [36] } \\
\hline$>37$ & 50 & 2.33 & 0.36 & 2.0 & 68 & 22 & \\
\hline $\mathrm{p}$ & --- & $<0.005$ & NS & $<0.001$ & NS & $<0.05$ & \\
\hline \multicolumn{8}{|l|}{ Ceftazidime } \\
\hline 35 & 50 & na & na & 4.7 & 109 & 12 & \multirow[t]{3}{*}[41]{} \\
\hline 37 & $50 \mathrm{IM}$ & na & na & 3.8 & 53 & 9.0 & \\
\hline $\mathrm{p}$ & --- & --- & --- & $<0.05$ & $<0.001$ & $<0.05$ & \\
\hline$\leq 32$ & \multirow[t]{3}{*}{ Note A } & 0.98 & 0.53 & 6.7 & 111 & 41 & \multirow[t]{3}{*}{ [42] } \\
\hline$\geq 38$ & & 1.42 & 0.48 & 4.2 & 102 & 29 & \\
\hline $\mathrm{p}$ & & $\mathrm{P}<0.05$ & NS & NS & NS & $<0.05$ & \\
\hline \multirow[t]{2}{*}{$25-42$} & $25 \times 2$ & 0.84 & 0.46 & 7.3 & 77 & 16 & \multirow{3}{*}{ [43] } \\
\hline & $25 \times 2 \mathrm{IM}$ & 0.63 & 0.40 & 14.2 & 56 & 20 & \\
\hline $\mathrm{p}$ & --- & NS & NS & $<0.01$ & $<0.02$ & NS & \\
\hline $31^{\mathrm{a}}$ & $50 \times 2$ & 0.68 & 0.36 & 6.3 & na & na & \multirow[t]{3}{*}{ [44] } \\
\hline $29^{b}$ & $50 \times 2$ & 0.46 & 0.36 & 9.4 & na & na & \\
\hline $\mathrm{p}$ & --- & $<0.05$ & NS & $<0.05$ & --- & --- & \\
\hline $29^{c}$ & $25 \times 2$ & 0.51 & 0.36 & 8.7 & na & na & [45] \\
\hline $29^{d}$ & $25 \times 2$ & 0.69 & 0.29 & 5.0 & na & na & \\
\hline $\mathrm{p}$ & -- & $<0.05$ & $<0.005$ & $<0.005$ & -- & --- & \\
\hline 29 & 25 & 0.46 & 0.32 & 8.1 & na & 13.1 & [46] \\
\hline 29 & $25 \times 2$ & 0.41 & 0.30 & 7.1 & na & 42.0 & \\
\hline $\mathrm{p}$ & --- & NS & NS & NS & NS & $<0.001$ & \\
\hline Ceftriazone & & & & & & & \\
\hline $\mathrm{na}^{\mathrm{a}}$ & 50 & 0.37 & 0.45 & 16.2 & 124 & 34 & [49] \\
\hline $\mathrm{na}^{\mathrm{b}}$ & Note A & 0.70 & 0.57 & 10.4 & 188 & 23 & \\
\hline $\mathrm{p}$ & -- & 0.02 & NS & 0.001 & 0.04 & NS & \\
\hline
\end{tabular}


Table 4. Cont.

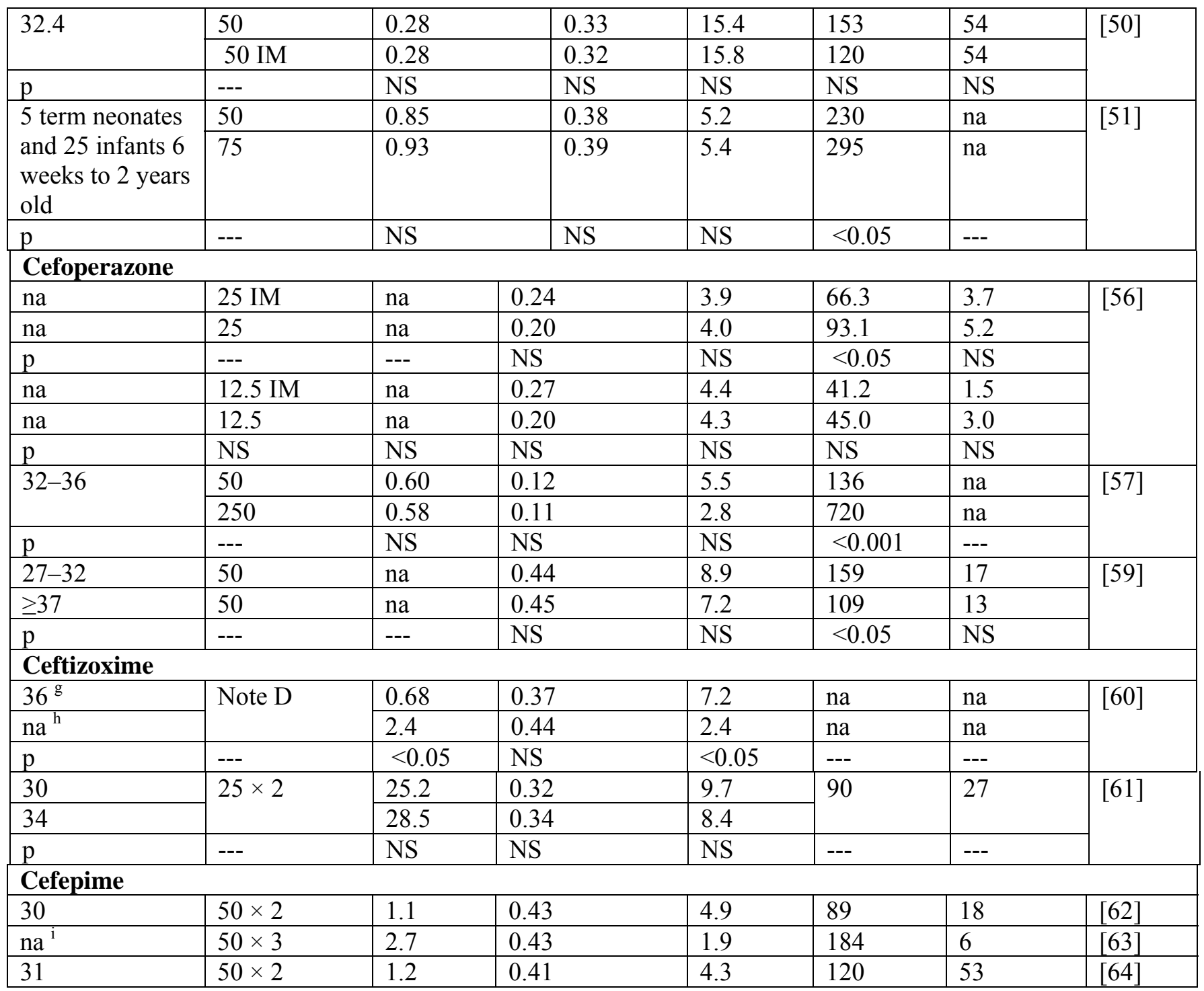

na $=$ not available. $\mathrm{IM}=$ intramuscular. $\mathrm{NS}=$ not significant. Note A: Cefotaxime dose was 25 $\mathrm{mg} / \mathrm{kg}$ and $50 \mathrm{mg} / \mathrm{kg}$ in patients with meningitis. Doses were administered every $12 \mathrm{~h}$ in neonates less than one week of age, and every $8 \mathrm{~h}$ in patients 1 to 4 weeks of postnatal age. ${ }^{a}$ Controls. ${ }^{\mathrm{b}}$ Treated with indomethacin. ${ }^{\mathrm{c}} 3$ days old. ${ }^{\mathrm{d}} 10$ days old. na $=$ not available. Note B: Dose of ceftazidime was $50 \mathrm{mg} / \mathrm{kg}$ every $12 \mathrm{~h}$ for neonates in the first week of life and every $8 \mathrm{~h}$ for older infants. Postnatal age of 1.7 days $^{\mathrm{e}}$ and 17.4 days ${ }^{\mathrm{f}}$. Note C: 3 patients received $50 \mathrm{mg} / \mathrm{kg} ; 4$ patients received $100 \mathrm{mg} / \mathrm{kg}$ and 1 patient received $144 \mathrm{mg} / \mathrm{kg}$ ceftriaxone intravenously. Body weight $2,600{ }^{\mathrm{g}}$ and $4,600{ }^{\mathrm{h}}$. ${ }^{\mathrm{i}}$ Postnatal age ranged from 2 to 6 months. Note D: 25 patients received 25 $\mathrm{mg} / \mathrm{kg}$ and 27 patients received $50 \mathrm{mg} / \mathrm{kg}$.

\subsection{Second generation cephalosporins}

\subsubsection{Cefoxitin (see Table 4)}

The pharmacokinetics of cefoxitin was studied by Regazzi et al. [32]. The half-life negatively correlated with postnatal age $(\mathrm{r}=-0.58 ; \mathrm{p}<0.05)$. Young and Mangum [8] suggested administering $25-33 \mathrm{mg} / \mathrm{kg}$ cefoxitin every 8 to $12 \mathrm{~h}$ when the postmenstrual age ranged from $\leq 29$ to $\leq 44$ weeks. When the post-menstrual age is $\geq 45$ weeks the interval between doses should be $6 \mathrm{~h}$. 


\subsubsection{Cefuroxime (see Table 4)}

Renlund and Pettay [33] studied the pharmacokinetics of cefuroxime in 104 neonates. The serum concentration of cefuroxime decreased with the body weight from $25.6 \mu \mathrm{g} / \mathrm{mL}$ ( $<1 \mathrm{~kg}$ body weight) to $19.5 \mu \mathrm{g} / \mathrm{mL}$ ( $>4 \mathrm{~kg}$ body weight). $\mathrm{t}_{1 / 2}$ had a consistent behaviour and decreased from $5.6 \mathrm{~h}(2.83 \mathrm{~kg}$ body weight) to $4.0 \mathrm{~h}$ (3.83 kg body weight). Cefuroxime did not accumulate over a period of 8 days and this drug was excreted in the urine for over $70 \%$.

\subsubsection{Cefotaxime (see Table 4)}

Four original studies on the pharmacokinetics of cefotaxime compare the kinetic parameters of this drug in preterm and term infants [34-37]. The gestational age ranged from 28 to 33 weeks in preterm infants and between 37 and 38 in term infants. $\mathrm{Cl}$ is higher in term than preterm infants and $\mathrm{t}_{1 / 2}$ is longer in preterm than term infants. $\mathrm{Vd}$, peak and trough concentrations were not different in preterm and term infants. Gouyon et al. [38] observed that $t_{1 / 2}$ of cefotaxime negatively correlates with gestational age $(\mathrm{r}=-0.8954 ; \mathrm{p}<0.01)$ and with body weight $(\mathrm{r}=-0.8500 ; \mathrm{p}<0.01)$. In contrast, $\mathrm{Cl}$ positively correlated with gestational age $(r=0.7280 ; p<0.02)$ and with body weight $(r=0.8667 ; p<0.02)$.

Cefotaxime is converted into desacetylcefotaxime in the neonate and the peak concentration of desacetylcefotaxime is about one tenth of that of cefotaxime [38-40]. After $50 \mathrm{mg} / \mathrm{kg}$ cefotaxime, $50 \%$ to $60 \%$ of the dose is excreted unchanged in the urine and about $20 \%$ is excreted as desacetylcefotaxime [39]. The renal $\mathrm{Cl}$ of cefotaxime is quantitatively more important than the metabolic $\mathrm{Cl}$ of this drug.

Young and Mangum [8] suggested a cefotaxime dose of $50 \mathrm{mg} / \mathrm{kg}$ every 12 or $8 \mathrm{~h}$ when the postmenstrual age ranged from $\leq 29$ to $\leq 44$ weeks. when the postmenstrual age was $\geq 45$ weeks, cefotaxime should be administerd every $6 \mathrm{~h}$.

\subsubsection{Ceftazidime (see Table 4)}

Boccazzi et al. [41] described the pharmacokinetics of ceftazidime after intravenous and oral administration. Peak plasma concentration was doubled after intravenous compared with oral concentration.

McCracken et al. [42] described the pharmacokinetics of ceftazidime in two groups of neonates with a gestational age of $\leq 32$ and $\geq 38$ weeks. There was a considerable variation in the concentration of ceftazidime. $\mathrm{Cl}$ increased with the gestational age whereas $t_{1 / 2}$ and the trough concentrations decreased with the gestational age.

$\mathrm{Cl}$ of ceftazidime increased with postnatal age $(\mathrm{r}=0.7035 ; \mathrm{p}<0.0001)$ and an opposite trend was observed with $\mathrm{t}_{1 / 2}$ and the postnatal age $[\mathrm{r}=-0.4951 ; \mathrm{p}<0.001 ; 43]$. In the six infants examined, ceftazidime penetrated into the oropharyngeal secretion at concentrations equal to the $\mathrm{MIC}_{90}$ for Pseudomonas aeruginosa. The urine ceftazidime concentration was measured in 23 infants and it varied from 192 to $6,028 \mu \mathrm{g} / \mathrm{mL}$. There was a dramatic effect of gestational age on the excretion of ceftazidime in the urine and in the serum $\mathrm{Cl}$.

Prenatal exposure to indomethacin results in significantly lower GFR and ceftazidime $\mathrm{Cl}$ [44]. $\mathrm{Cl}$ of ceftazidime was $0.46 \mathrm{~mL} / \mathrm{min} / \mathrm{kg}(\mathrm{No}=23)$ in neonates who were exposed prenatally to indomethacin 
and $0.68 \mathrm{~mL} / \mathrm{min} / \mathrm{mg}(\mathrm{No}=84)$ in infants who were not exposed to indomethacin $(\mathrm{p}<0.05)$. Cl of ceftazidime correlated with gestational age $(r=0.83 ; p<0.001)$ whereas $t_{1 / 2}$ had an opposite trend $(\mathrm{r}=-0.54 ; \mathrm{p}<0.001 ; 44)$. The positive relationship between $\mathrm{Cl}$ of ceftazidime and $\mathrm{Cl}$ of inulin $(\mathrm{r}=0.73 ; \mathrm{p}<0.001)$ indicates that glomerular filtration has an important effect on the $\mathrm{Cl}$ of ceftazidime. However, the variability in $\mathrm{Cl}$ of ceftazidime exceeds $\mathrm{Cl}$ of inulin; this indicates that ceftazidime is not eliminated by glomerular filtration alone. Van den Anker et al. [44] propose that tubular reabsorption or tubular secretion is involved in the renal handling of ceftazidime in neonates. $\mathrm{Cl}$ of ceftazidime correlated with the reciprocal of the serum concentration of creatinine $(\mathrm{r}=0.72$; $\mathrm{p}<0.001$ ) suggesting that this compound may interfere with the renal clearance of ceftazidime.

Ceftazidime $\mathrm{Cl}$ increases from day 3 to day 10 of life [45]. Such an increase was due to the increase of GFR. The inulin $\mathrm{Cl}$ is 0.72 (day 3) and $0.91 \mathrm{~mL} / \mathrm{min}$ (day 10) (p<0.05). $\mathrm{Cl}$ of ceftazidime correlated with GFR $(r=0.81 ; p<0.001)$. Such a correlation indicates the important role of GFR in the ceftazidime $\mathrm{Cl}$. Vd of ceftazidime decreases between from day 3 to day 10 of life. During the first week of life there is a significant decrease of the extracellular water and ceftazidime is mainly distributed into the extracellular water component and the decrease of extracellular water may cause the decrease of ceftazidime $\mathrm{Vd}$ in the period 3 to 10 days of life. Postnatal exposure to indomethacin prevents the pharmacokinetic modification seen from the day 3 to 10 of life. This may be explained by the dependence of postnatal changes in extracellular water on renal function [45] and the impairment of GFR with the use of indomethacin.

Once-daily versus twice-daily administration of ceftazidime was studied by van den Anker et al. [46]. After $25 \mathrm{mg} / \mathrm{kg}$ twice-daily, the trough concentration of ceftazidime is too high $(42.0 \mu \mathrm{g} / \mathrm{mL})$ whereas the trough concentration of ceftazidime after once-daily dosing is $13.1 \mu \mathrm{g} / \mathrm{mL}$ and is greater than major neonatal pathogens $\mathrm{MIC}_{99}$ such as Streptococcus agalactiae and Escherichia coli $\left(\mathrm{MIC}_{99}<0.25 \mu \mathrm{g} / \mathrm{mL}\right) ;[47,48]$. Therefore, these authors suggested that once-daily $25 \mathrm{mg} / \mathrm{kg}$ ceftazidime is the appropriate therapeutic schedule of ceftazidime in the neonate. $\mathrm{Cl}$ ranged from 0.41 to $1.42 \mathrm{~mL} / \mathrm{min} / \mathrm{kg}, \mathrm{Vd}$ ranged between 0.29 and $0.53 \mathrm{~L} / \mathrm{kg}$ and $\mathrm{t}_{1 / 2}$ ranged from 3.8 to $14.2 \mathrm{~h}$.

Young and Mangum [8] suggested administrating $30 \mathrm{mg} / \mathrm{kg}$ ceftazidime every 8 or $12 \mathrm{~h}$ according to the postmenstrual age $\leq 29$ weeks and $\leq 44$ weeks. When the postmenstrual age is $\geq 45$ weeks, ceftazidime should be administered every $8 \mathrm{~h}$.

\subsubsection{Ceftriaxone (see Table 4)}

Martin et al. [49] studied the kinetics of ceftriaxone in 12 neonates. Four neonates received $50 \mathrm{mg} / \mathrm{kg}$ ceftriaxone whereas eight received a dose of ceftriaxone ranging from 50 to $144 \mathrm{mg} / \mathrm{kg}$ (see note $\mathrm{A}$ in Table 4). The gestational age as well was different in the two groups; it was 1.7 days in the first group and 17.4 days in the second group. $\mathrm{Cl}$ was greater in the former group, whereas $\mathrm{t}_{1 / 2}$ had an opposite trend. Such a difference could be due to the different development stage of neonates in the two groups. The peak concentration was greater in the neonates of the second group that received a higher dose of ceftriaxone. The intravenous and intramuscular administration of ceftriaxone yielded similar kinetic parameters [50]. Steele et al. [51] observed that the peak concentration of ceftriaxone was higher after 75 than after $50 \mathrm{mg} / \mathrm{kg}$. Cl ranged from 0.28 to $0.93 \mathrm{~mL} / \mathrm{min} / \mathrm{kg}, \mathrm{Vd}$ ranged between 0.32 and $0.57 \mathrm{~L} / \mathrm{kg}$ and $\mathrm{t}_{1 / 2}$ ranged from 5.2 and $16.2 \mathrm{~h}$. Young and Mangum [8] suggested 
administrating $50 \mathrm{mg} / \mathrm{kg}$ every $24 \mathrm{~h}$. For treatment of meningitis give $100 \mathrm{mg} / \mathrm{kg}$ loading dose, then $80 \mathrm{mg} / \mathrm{kg}$ once daily.

Ceftriaxone should not be administered to neonates as it displaces bilirubin from albumin binding sites resulting in higher free bilirubin serum concentration [52,53]. Even more dangerous is the interaction of ceftriaxone with calcium. Such an interaction yields precipitation of calcium which resulted in serious adverse effect [54,55]. A particular serious effect is the precipitation of calcium in the lungs and death.

\subsubsection{Cefoperazone (see Table 4)}

Varghese et al. [56] compared the kinetic parameters of cefoperazone after intramuscular and intravenous administration. The two administrations differ for the peak concentration that is higher after intravenous than intramuscular administration after a dose of $25 \mathrm{mg} / \mathrm{kg}$ cefoperazone. After a dose of $12.5 \mathrm{mg} / \mathrm{kg}$ cefoperazone there is no difference in the peak concentration between intramuscular and intravenous administration.

Bosso et al. [57] observed that the gestational age correlates with $\mathrm{Cl}(\mathrm{r}=0.67 ; \mathrm{p}=0.01)$ and with constant of elimination $(\mathrm{r}=0.57 ; \mathrm{p}<0.05) . \mathrm{t}_{1 / 2}$ decreased with advancing gestational age $(\mathrm{r}=-0.81$; $\mathrm{p}<0.001 ;$ [58]). Vd ranged from 0.11 to $0.45 \mathrm{~L} / \mathrm{kg}$ and $\mathrm{t}_{1 / 2}$ ranged from 3.9 to $8.9 \mathrm{~h}$.

Rosenfeld et al. [59] compared the kinetic parameters of cefoperazone in preterm and term infants after a dose of $50 \mathrm{mg} / \mathrm{kg}$. The only parameter that differs in the two development stages is the peak concentration which is greater in preterm than in term neonates. Vd ranged from 0.11 and $0.45 \mathrm{~L} / \mathrm{kg}$ and $\mathrm{t}_{1 / 2}$ ranged between 2.8 and $8.9 \mathrm{~h}$.

\subsubsection{Ceftizoxime (see Table 4)}

The pharmacokinetics of ceftizoxime were studied in 52 infants whose postnatal age ranged from 1 to 189 days [60]. $\mathrm{t}_{1 / 2}$ diminished steadily as the postnatal aged increased whereas $\mathrm{Cl}$ had an opposite trend. Vd remained relatively constant. Ceftizoxime is excreted unchanged essentially by renal route [60]. Ceftizoxime $\mathrm{Cl}$ and $\mathrm{Vd}$ were strongly influenced by the body weight whereas the influence of gestational age on $\mathrm{Cl}$ and $\mathrm{Vd}$ was negligible [61]. $\mathrm{Cl}$ ranged from 0.68 to $28.5 \mathrm{~mL} / \mathrm{min} / \mathrm{kg}, \mathrm{Vd}$ ranged from 0.32 to $0.44 \mathrm{~L} / \mathrm{kg}$, and $\mathrm{t}_{1 / 2}$ ranged between 2.4 and $9.7 \mathrm{~h}$.

Young and Mangum [8] suggested administrating $50 \mathrm{mg}$ ceftriaxone once daily. For treatment of meningitis, administrate a loading dose of $100 \mathrm{mg} / \mathrm{kg}$ followed by a daily dose of $80 \mathrm{mg} / \mathrm{kg}$ ceftriaxone.

\subsection{Fourth generation cephalosporins}

\subsubsection{Cefepime (see Table 4)}

The serum creatinine concentration negatively correlates $(r=-0.79)$ with cefepime $\mathrm{Cl}$ in neonates [62]. The serum concentration of creatinine is a strong predictor of cefepime $\mathrm{Cl}$ and the relationship between serum creatinine and $\mathrm{Cl}$ is similar across the range of gestational ages [62]. The relationship between cefepime $\mathrm{Cl}$ and gestational age is not significant. The development of the renal excretory function is an important determinant of cephalosporin dosing, including cefepime, in the neonate. In the premature, the renal function is impaired. Since cefepime is mainly excreted 
unchanged [62], the premature and term neonates clear cefepime more slowly than more mature infants. In neonates, cefepime $\mathrm{Cl}$ is about $40 \%$ of that in more mature infants, which results in a longer $\mathrm{t}_{1 / 2}$ and higher trough concentration in neonates. $\mathrm{Vd}$ is larger in infants less than 30 weeks of postconceptional life than in term neonates [62]. This is consistent with the larger total body water in the extremely premature neonate.

Reed et al. [63] described the pharmacokinetics of cefepime in 37 infants and children aged between 2 months and 16 years. The data are grouped on age; the youngest patients ranged between 2 and 6 months of age and the pharmacokinetic results of these patients are reported in Table 4 . Ninety percent of cefepime was recovered in the urine over $24 \mathrm{~h}$ of urine collection; thus the elimination of cefepime is in large part via the kidneys. The data relative to cefepime revealed disposition parameters similar to those of third-generation cephalosporins, including linearity over a broad dose range (250-2000 mg), limited disposition and $\mathrm{Cl}$ mainly by the kidneys.

Lima-Rogel et al. [64] compared their own results on the pharmacokinetics of cefepime in neonates with those by Capparelli et al. [62] and with those by Reed et al. [63]. The pharmacokinetic parameters by Lima-Rogel et al. [64] and those by Capparelli et al. [52] were obtained in infants with similar demographic data $\mathrm{t}_{1 / 2}$ and $\mathrm{Cl}$ are comparable in these two studies. Reed et al. [63] described the pharmacokinetics of cefepime in older infants and children and in this study, $\mathrm{t}_{1 / 2}$ was one half and $\mathrm{Cl}$ was double those in the neonates. $\mathrm{Cl}$ ranged from 1.1 and $2.7 \mathrm{~mL} / \mathrm{min} / \mathrm{mg}, \mathrm{Vd}$ ranged between 0.41 and $0.43 \mathrm{~L} / \mathrm{kg}$ and $\mathrm{t}_{1 / 2}$ ranged from 1.9 to $4.9 \mathrm{~h}$.

The findings more relevant from a clinical point of view are as follows. A feature common to cephalosporins is the remarkable interindividual variability of their kinetic parameters. Such a variability is due to renal maturation as cephalosporin are fairly water soluble and are eliminated with the urine. $t_{1 / 2}$ of cefotaxime, of ceftazidime and of ceftizoxime decrease with gestational and postnatal ages. $t_{1 / 2}$ of cephalosporins ranged over a wide interval and the highest value (14.2 h) was observed for ceftazidime after intramuscular administration. Cephalosporins are safe, clinically effective and easy to use and the first and second generation are mostly used to treat infection sustained by Gram-positive bacteria, whereas the cephalosporins of the third and fourth generation are active against Grampositive and several Gram-negative bacteria.

\section{Aminoglycosides}

Table 5. Number of retrieved studies and number of drugs evaluated.

\begin{tabular}{|l|c|c|c|}
\hline \multicolumn{1}{|c|}{ Drug } & $\begin{array}{c}\text { Number of } \\
\text { retrieved studies }\end{array}$ & $\begin{array}{c}\text { Number of drugs } \\
\text { evaluated }\end{array}$ & $\begin{array}{c}\text { Overall number of } \\
\text { neonates studied }\end{array}$ \\
\hline Gentamicin & 12 & 1 & 792 \\
Netilmicin & 10 & 1 & 510 \\
Tobramycin & 3 & 1 & 22 \\
Amikacin & 7 & 1 & 369 \\
\hline Total & 32 & 4 & 1693 \\
\hline
\end{tabular}




\subsection{Gentamicin (see Table 6)}

Aminoglycosides are toxic for the eighth cranial nerve [65,66] and for the kidney $[65,67]$. This requires the concentration of aminoglycosides to be within the appropriate interval. Gentamicin trough concentration $>2 \mu \mathrm{g} / \mathrm{mL}$ is associated with toxicity [65,70] and peak concentration $<5 \mu \mathrm{g} / \mathrm{mL}$ is associated with lesser efficacy [65,69] as gentamicin, as well as the other aminoglycosides, exhibits a concentration-depended bactericidal effect [65]. Formerly, gentamicin was administered at a dose of $2.5 \mathrm{mg} / \mathrm{kg}$ every $12 \mathrm{~h}$ [70]. Later, it appeared that once-daily gentamicin dosing of 4-5 mg/kg yields higher peak and lower trough gentamicin concentration than twice-daily dosing [for review see Rao et al. [71] and Miron [72]. Recently, administering $5 \mathrm{mg} / \mathrm{kg}$ gentamicin and extending the dose interval to 36-48 $\mathrm{h}$ has been recommended [73-78]. Extending the dose interval to $48 \mathrm{~h}$ and increasing the gentamicin dose to $5 \mathrm{mg} / \mathrm{kg}$ causes an increase in peak concentration as compared with the dose of

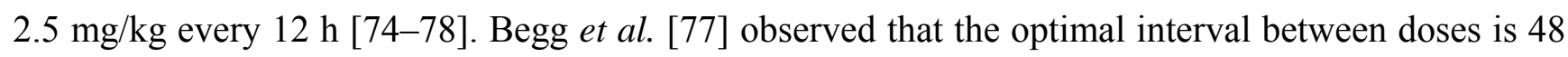
$\mathrm{h}, 36 \mathrm{~h}$, and $24 \mathrm{~h}$ for neonates whose body weight is $<1 \mathrm{~kg}, 1-2.49 \mathrm{~kg}$ and $\geq 2.5 \mathrm{~kg}$, respectively. The extended-interval method of aminoglycosides has been used in $75 \%$ of US hospitals since $2002[79,80]$. Cl ranged from 0.53 to $0.93 \mathrm{~mL} / \mathrm{min} / \mathrm{mg}$, Vd ranged between 0.46 and $0.76 \mathrm{~L} / \mathrm{kg}$, and $\mathrm{t}_{1 / 2}$ ranged from 5.5 to $12 \mathrm{~h}$.

Young and Mangum [8] suggested a gentamicin dose of $5 \mathrm{mg} / \mathrm{kg}$ every $48 \mathrm{~h}$ during the first week of life, when the gestational age is $\leq 29$ weeks, a dose of $4.5 \mathrm{mg} / \mathrm{kg}$ every $36 \mathrm{~h}$, during the first week of life, when the gestational age is 30 to $34 \mathrm{~h}$ and a daily dose of $4 \mathrm{mg} / \mathrm{kg}$ when the gestational age is $\geq 35$ weeks.

Table 6. Pharmacokinetic parameters of aminoglycosides. Figures are the mean or range.

\begin{tabular}{|c|c|c|c|c|c|c|c|}
\hline $\begin{array}{l}\text { Gestational } \\
\text { age (weeks) }\end{array}$ & $\begin{array}{l}\text { Daily dose } \\
\text { (mg/kg) }\end{array}$ & $\begin{array}{c}\mathrm{Cl} \\
(\mathrm{mL} / \mathrm{min} / \mathrm{kg})\end{array}$ & $\begin{array}{c}\text { Vd } \\
(\mathrm{L} / \mathrm{kg})\end{array}$ & $\mathbf{t}_{1 / 2}(\mathbf{h})$ & $\begin{array}{c}\text { Peak conc. } \\
(\mu \mathrm{g} / \mathrm{mL})\end{array}$ & $\begin{array}{c}\text { Trough } \\
\text { conc. } \\
(\mu \mathrm{g} / \mathrm{mL})\end{array}$ & Ref \\
\hline \multicolumn{8}{|l|}{ Gentamicin } \\
\hline $26-32$ & 2.5 every $18 \mathrm{~h}$ & $0.93 \mathrm{~mL} / \mathrm{min}$ & na & 12.0 & 6.3 & 1.6 & {$[70]$} \\
\hline 26 & 2.5 & 0.53 & 0.50 & 10.2 & 5.9 & 1.3 & \multirow[t]{3}{*}[81]{} \\
\hline 31 & 3.0 & 0.62 & 0.49 & 8.9 & 6.8 & 1.2 & \\
\hline 38 & 4.0 & 0.78 & 0.46 & 7.0 & 8.9 & 1.3 & \\
\hline 34 & $2.5 \times 2$ & na & na & na & 3.8 & 2.8 & {$[82]$} \\
\hline 34 & 4 & na & na & na & 5.9 & 1.6 & \\
\hline $\mathrm{p}$ & --- & --- & --- & --- & $<0.001$ & $<0.05$ & \\
\hline 36 & $2.5 \times 2$ & na & na & na & 6.4 & 2.2 & \multirow[t]{3}{*}[83]{} \\
\hline 35 & 5 & na & na & na & 9.5 & 1.4 & \\
\hline $\mathrm{p}$ & --- & --- & --- & --- & $<0.001$ & $<0.005$ & \\
\hline $37-41$ & $2.5 \times 2$ & na & na & 5.9 & 6.4 & 1.9 & \multirow[t]{3}{*}[84]{} \\
\hline $37-41$ & 4 & na & na & 5.5 & 8.2 & 0.9 & \\
\hline $\mathrm{p}$ & --- & -- & -- & na & $<0.001$ & $<0.0001$ & \\
\hline 29 & 2.5 & na & 0.76 & 11.1 & 6.0 & 1.25 & \multirow{3}{*}[73]{} \\
\hline 28 & $\begin{array}{l}5 \text { every } \\
48 \mathrm{~h} \\
\end{array}$ & na & 0.76 & 10.7 & 8.1 & 1.72 & \\
\hline $\mathrm{p}$ & --- & --- & NS & NS & $<0.0001$ & $<0.001$ & \\
\hline 27 & 2.5 & na & 0.61 & 10.0 & 5.8 & 1.2 & \multirow[t]{3}{*}[74]{} \\
\hline 27 & 5 every $48 \mathrm{~h}$ & na & 0.66 & 10.3 & 8.0 & 0.7 & \\
\hline $\mathrm{p}$ & --- & --- & NS & NS & $<0.01$ & NS & \\
\hline
\end{tabular}


Table 6. Cont.

\begin{tabular}{|c|c|c|c|c|c|c|c|}
\hline \multicolumn{8}{|c|}{ Netilmicin } \\
\hline$<34$ & 4.5 & $1.5(\mathrm{~mL} / \mathrm{min})$ & 0.46 & 7.6 & 6.7 & 1.2 & \multirow[t]{3}{*}[85]{} \\
\hline $34-36$ & 4.5 & $\begin{array}{l}1.33 \\
(\mathrm{~mL} / \mathrm{min})\end{array}$ & 0.51 & 8.5 & 8.6 & 1.4 & \\
\hline$>36$ & 4.5 & $\begin{array}{l}3.16 \\
(\mathrm{~mL} / \mathrm{min})\end{array}$ & 0.51 & 6.1 & 7.2 & 0.9 & \\
\hline 29 & 6 & 0.45 & 0.52 & 6.6 & 5.0 & 2.7 & \multirow[t]{3}{*}[86]{} \\
\hline 35 & 6 & 0.45 & 0.46 & 6.7 & 6.2 & 2.8 & \\
\hline 40 & 6 & 0.64 & 0.41 & 4.6 & 6.6 & 1.9 & \\
\hline 35 & 3 (IM) & na & 0.61 & 4.7 & 5.6 & 2.7 & {$[87]$} \\
\hline 28 & 6 every $36 \mathrm{~h}$ & na & na & 17.8 & 10 & 4.8 & {$[88]$} \\
\hline 30 & $2.5 \times 2$ & 0.84 & 0.60 & 8.6 & 9.0 & 2.8 & [89] \\
\hline 35 & $2.5 \times 2(\mathrm{IM})$ & 1.06 & 0.34 & 9.6 & 7.7 & 2.6 & [90] \\
\hline \multicolumn{8}{|c|}{ Tobramycin } \\
\hline 28 & Note A & 0.69 & 0.59 & 9.9 & 7.6 & 1.7 & {$[92]$} \\
\hline 29 & Note B & 0.72 & $\begin{array}{l}0.74- \\
0.94 \\
\end{array}$ & $8.3-12.8$ & $4.6-8.4$ & $1.2-2.0$ & [93] \\
\hline na & 5 (IM) & $4.9(\mathrm{~mL} / \mathrm{min})$ & 0.49 & 4.4 & 2.7 & na & [94] \\
\hline \multicolumn{8}{|c|}{ Amikacin } \\
\hline 36 & 7.5 (IM) & 1.42 & 0.66 & 6.0 & 18.6 & na & {$[97]$} \\
\hline 32 & 5 (IM) & 0.96 & 0.72 & $9.0^{*}$ & na & na & \multirow[t]{2}{*}[98]{} \\
\hline 40 & 1.24 & 0.56 & 0.55 & $5.5^{*}$ & na & na & \\
\hline 34 & 5 (IM) & 0.86 & 0.49 & 6.8 & na & na & [99] \\
\hline 30 & Note A & 0.84 & 0.57 & 8.4 & 23.9 & 8.3 & {$[100]$} \\
\hline $37^{\mathrm{a}}$ & Note B & 2.05 & 0.34 & 2.8 & $6.8-35.7$ & $<0.8-17.7$ & [101] \\
\hline 38 & $7.5-10$ & 1.71 & 0.64 & 3.7 & na & na & {$[102]$} \\
\hline $27^{b}$ & Note $E$ & $0.36^{\mathrm{d}}$ & $0.63^{\mathrm{d}}$ & $16.4^{\mathrm{d}}$ & $47.7^{d}$ & $9.9^{\mathrm{d}}$ & \multirow{3}{*}[105]{} \\
\hline $28^{\mathrm{c}}$ & Note E & $0.60^{d}$ & $0.59^{\mathrm{d}}$ & $12.4^{\mathrm{d}}$ & $40.9^{d}$ & $6.2^{\mathrm{d}}$ & \\
\hline $\mathrm{p}$ & $\mathrm{NS}$ & $<0.005$ & NS & $<0.02$ & NS & $<0.01$ & \\
\hline
\end{tabular}

na $=$ not available. $\mathrm{NS}=$ not significant. $\mathrm{IM}=$ intramuscular. ${ }^{\mathrm{a}}$ The postnatal age was 450 days and the body weight was $7.4 \mathrm{~kg} .{ }^{\mathrm{b}}$ Ibuprofen. ${ }^{\mathrm{c}}$ Placebo. ${ }^{\mathrm{d}}$ Median. ${ }^{*} \mathrm{p}=0.009$. Note A: $2.5 \mathrm{mg} / \mathrm{kg}$ every $18 \mathrm{~h}$ or $3 \mathrm{mg} / \mathrm{kg}$ every $24 \mathrm{~h}$. Note B: $2.5 \mathrm{mg} / \mathrm{kg}$ every 12 or $18 \mathrm{~h}$. Note C: $7.5 \mathrm{mg} / \mathrm{kg}$ every $12 \mathrm{~h}$ when the chronologic life was up to 7 days and $7.5 \mathrm{mg} / \mathrm{kg}$ every $8 \mathrm{~h}$ when the chronologic life was $>7$ days. Note $\mathrm{D}$ : the loading dose was $11.7 \pm 1.3$ and the maintenance dose was $9.8 \pm 1.4 \mathrm{mg} / \mathrm{kg}$. In the first drug dosing regimen, neonates received a loading dose of $10 \mathrm{mg} / \mathrm{kg}$ amikacin followed by a maintenance dose of $7.5 \mathrm{mg} / \mathrm{kg}$ every $12 \mathrm{~h}$. The infants and children received $7.5 \mathrm{mg} / \mathrm{kg}$ amikacin every $12 \mathrm{~h}$. In the second drug dosing regimen, we considered an infusion of $15 \mathrm{mg} / \mathrm{kg}$ amikacin every $12 \mathrm{~h}$ for neonates, infants and children. Note E: $20 \mathrm{mg} / \mathrm{kg}$ every $36 \mathrm{~h}$ when gestational age was $<30$ weeks and $20 \mathrm{mg} / \mathrm{kg}$ every $24 \mathrm{~h}$ when gestational age was $\geq 30$ weeks.

\subsection{Netilmicin (see Table 6)}

Table 6 shows the pharmacokinetic parameters of netilmicin at different gestation ages, different dosages and different administration routes. With increasing the gestational age from $<34$ to $>36$, $\mathrm{t}_{1 / 2}$ decreases from 7.6 to $6.1 \mathrm{~h}$ [85]. This is due to the development of the renal excretory function, as gentamicin, as well as the other aminoglycosides, is mainly eliminated by renal route. Administering $4.5 \mathrm{mg} / \mathrm{kg}$ netilmicin, Gosden et al. [ 85] have observed that the netilmicin peak concentration, which is expected to be $>5$ and $<12 \mu \mathrm{g} / \mathrm{mL}$ and the trough concentration that should be $<2 \mu \mathrm{g} / \mathrm{mL}$, were 
within the expected values. Ettlinger et al. [86] made similar observations; when the gestational age increased from 29 to 40 week, $\mathrm{t}_{1 / 2}$ decreased from 6.6 to $4.6 \mathrm{~h}$ and the trough concentration decreased from 2.7 to $1.9 \mu \mathrm{g} / \mathrm{mL}$. In this study, the trough concentration was $>2 \mu \mathrm{g} / \mathrm{mL}$ in one third of the cohort. It must be noted that the trough concentration was measured $6 \mathrm{~h}$ after administration. The kinetic parameters of netilmicin are similar after intravenous and intramuscular administration [87]. The only information on the extended-interval administration of netilmicin was reported by Klingenberg et al. [87]. These authors administerd $6 \mathrm{mg} / \mathrm{kg}$ netilmicin every $36 \mathrm{~h}$ and report a very long $\mathrm{t}_{1 / 2}$ of $17.8 \mathrm{~h} ; \mathrm{Cl}$ is not available and the peak and trough concentrations are higher than those obtained after dosing of $6 \mathrm{mg} / \mathrm{kg}$ netilmicin once-daily [86]. Klingenberg et al. [88] suggested a dosing interval of $48 \mathrm{~h}$ for gestational age $<29$ weeks, $36 \mathrm{~h}$ for gestational age ranging from $29-36 \mathrm{~h}$, and $24 \mathrm{~h}$ for full term infants. Kuhn et al. [89] and Granati et al. [90] observed that the trough concentration was $>2 \mu \mathrm{g} / \mathrm{mL}$ after administering $2.5 \mathrm{mg} / \mathrm{kg}$ twice daily. This suggests that once daily dose of 4 or $4.5 \mathrm{mg} / \mathrm{kg}$ netilmicin is safer than $2.5 \mathrm{mg} / \mathrm{kg}$ twice-daily. Recently, Sherwin et al. [91] proposed the following dosages of netilmicin $5 \mathrm{mg} / \mathrm{kg}$ ever $36 \mathrm{~h}, 6 \mathrm{mg}$ every $24 \mathrm{~h}$ and $7 \mathrm{mg} / \mathrm{kg}$ every $24 \mathrm{~h}$ for neonates $\leq 27$, 28-30 and $\geq 34$ weeks of postmenstrual age, respectively.

$\mathrm{Cl}$ ranged from 0.45 to $1.06 \mathrm{~mL} / \mathrm{min} / \mathrm{mg}, \mathrm{Vd}$ ranged between 0.34 and $0.61 \mathrm{~L} / \mathrm{kg}$, and $\mathrm{t}_{1 / 2}$ ranged from 4.6 to $17.8 \mathrm{~h}$. Young and Mangum [8] suggested a dose of netilmicin similar to that of gentamicin given above.

\subsection{Tobramycin (see Table 6)}

The information on the pharmacokinetics of tobramycin in the neonate is limited. Nahata et al. [92,93] reported two articles that were based on premature neonates. Peak concentration ranged between 4.6 and $8.4 \mu \mathrm{g} / \mathrm{mL}$ and the trough concentration ranged between 1.2 and $2.0 \mu \mathrm{g} / \mathrm{mL}$. Yoshioka et al. [94] administered $5 \mathrm{mg} / \mathrm{kg}$ tobramycin to neonates whose gestational age is unknown and the peak concentration was $2.7 \mu \mathrm{g} / \mathrm{mL}$. de Hoog et al. [95] administered $4 \mathrm{mg} / \mathrm{kg}$ to all patients and the interval between doses was $48 \mathrm{~h}$ ( $<32$ weeks), $36 \mathrm{~h}$ (32-36 weeks) and $24 \mathrm{~h}(\geq 37$ weeks). Using this dosage schedule the majority of infants had peak concentration from 5 to $10 \mu \mathrm{g} / \mathrm{mL}$ and the trough concentration ranged from 0.5 and $1 \mu \mathrm{g} / \mathrm{mL}$, then within the expected values.

Nonlinear mixed effects model (NONMEM) and nonparametric expectation maximization (NPEM2) were used to estimate population parameters of tobramycin kinetics in neonates [96]. NONMEM showed less bias $(\mathrm{p}<0.05)$ than NPEN2. Using NPEN2 Ke and Vd were $0.0079 \mathrm{~h}^{-1}$ and $0.65 \mathrm{~L} / \mathrm{kg}$, respectively. Young and Mangum [8] suggested a dose of tobramycin similar to that of gentamicin given above.

\subsection{Amikacin (see Table 6)}

Little is known on the pharmacokinetics of amikacin in the neonate. A study on the extended interval dosing of amikacin is lacking. Once-daily dosing of amikacin was administered by several authors [99]. $\mathrm{Cl}$ ranged between 0.56 and $1.42 \mathrm{~mL} / \mathrm{min} / \mathrm{kg}$, $\mathrm{Vd}$ ranged from 0.49 to $0.72 \mathrm{~L} / \mathrm{kg}$ and $\mathrm{t}_{1 / 2}$ ranged from 5.5 to $9.0 \mathrm{~h}$. Kenyon et al. [10] studied the pharmacokinetics of amikacin after twice-daily administration. $\mathrm{Cl}, \mathrm{Vd}$ and $\mathrm{t}_{1 / 2}$ were similar to those after once-daily dosing. These authors also measured the peak and trough concentrations that were 23.9 and $8.3 \mu \mathrm{g} / \mathrm{mL}$. Tréluyer et al. [101] 
studied the pharmacokinetics of amikacin in infants with a mean postnatal age and body weight of 450 days and $7.4 \mathrm{~kg}$, respectively. $\mathrm{Cl}$ was considerably higher than those found in neonates and $\mathrm{t}_{1 / 2}$ was shorter than those of neonates (Table 6). Wang et al. [102] studied the population pharmacokinetics of amikacin in 30 neonates with a mean gestational age of 38 weeks. These authors reported a $\mathrm{Cl}$ of $1.71 \mathrm{~mL} / \mathrm{min} / \mathrm{kg}$ and $\mathrm{t}_{1 / 2}$ of $3.7 \mathrm{~L} / \mathrm{kg}$ and these values considerably differ from those obtained in the previous studies, see table 6 .

Langhendries et al. [103] measured the peak and trough concentration of amikacin after once-daily and twice-daily dosing. After $15 \mathrm{mg} / \mathrm{kg}$ once-daily the peak was $23.1 \mu \mathrm{g} / \mathrm{mL}$ and, and after $7.5 \times 2$ it was $13.6 \mu \mathrm{g} / \mathrm{mL}$. The trough concentrations were similar with two dosages. These authors suggested administering $15 \mathrm{mg} / \mathrm{kg}$ once-daily as the peak concentration obtained after $7.5 \times 2$ dosing is too low. Sherwing et al. [104] recently suggested the following dosages of amikacin $15 \mathrm{mg} / \mathrm{kg}$ every $36 \mathrm{~h}$ when the gestational age is $\leq 28$ weeks, $14 \mathrm{mg} / \mathrm{kg}$ once-daily when the gestational age ranged from 29 to 26 weeks and $15 \mathrm{mg} / \mathrm{kg}$ once-daily when the gestational age is $\geq 37$ weeks. $\mathrm{Cl}$ ranged from 0.36 to $2.05 \mathrm{~mL} / \mathrm{min} / \mathrm{kg}, \mathrm{Vd}$ ranged between 0.49 and $0.72 \mathrm{~L} / \mathrm{kg}$, and $\mathrm{t}_{1 / 2}$ ranged from 2.8 to $16.4 \mathrm{~h}$.

Young and Mangum [8] suggested an amikacin dose of $18 \mathrm{mg} / \mathrm{kg}$ every $48 \mathrm{~h}$ during the first week of life when the postmenstrual age was $\leq 29$ weeks; a dose of $18 \mathrm{mg} / \mathrm{kg}$ every $36 \mathrm{~h}$ during the first week of life when the postmenstrual age was 30-34 weeks; and a daily dose of $15 \mathrm{mg} / \mathrm{kg}$ when the postmenstrual age was $\geq 35$ weeks.

The finding more relevant from a clinical point of view are reported hereafter. Aminoglycosides have a low therapeutic index and are toxic to the kidneyd and the acoustic nerve. To avoid toxicity, the peak and trough concentrations should be kept within the appropriate values which are $<12$ and $<2 \mu \mathrm{g} / \mathrm{mL}$, respectively, for gentamicin, netilmicin and tobramycin, and $<40$ and $<6 \mu \mathrm{g} / \mathrm{mL}$, respectively, for amikacin. For the therapeutic doses see the text and a useful source of information is obtainable from Young and Mangum [8]. Aminoglycosides are used for the treatment of neonates with Gram-negative bacterial infection, which is potentially life-threatening. Aminoglycosides are administered in association with a penicillin, such as ampicillin or amoxicillin, as penicillins increase bacterial permeability to aminoglycosides. The high morbidity and mortality of bacterial infection in neonates require that the antibiotic therapy should be started as soon as the infection is suspected.

\section{Discussion}

It is surprising that there have been few studies on the pharmacokinetics of penicillins, cephalosporins and aminoglycosides although they are key components of drug therapy in neonatal care units. The antibiotics that are more extensively studied are amoxicillin [16-21], cefotaxime [34-36], ceftazidime [41-46], gentamicin [70,73-77,81-84,106] and netilmicin [85-90,104]

Most of the studies on the pharmacokinetics of penicillins, cephalosporins and aminoglycosides are classical pharmacokinetic studies where several blood samples were taken from each patient. Nevertheless, few studies of population pharmacokinetics have been provided for benzylpenicillin [11], for amoxicillin [16,18,21], flucloxacillin [22], for gentamicin [75-79,107], for netilmicin [104] and for amikacin $[100,101]$. The results of the population pharmacokinetic studies are consistent with those of the classical pharmacokinetic investigations. 
Among penicillins, cephalosporins and aminoglycosides, this latter antibioticds are the most toxic, being toxic for the eighth cranial nerve $[65,66]$ and the kidneys $[65,67,68]$. This requires that the concentration of aminoglycosides range within the appropriate values. The peak concentration of gentamicin should be $>5 \mu \mathrm{g} / \mathrm{mL}$ and $<12 \mu \mathrm{g} / \mathrm{mL}$ and the trough concentration should be $<2 \mu \mathrm{g} / \mathrm{mL}$ [8]. This consideration also applies to netilmicin and tobramycin [8]. For amikacin the peak and the trough concentrations should be lower than 40 and $6 \mu \mathrm{g} / \mathrm{mL}$, respectively [8]. The dose and the interval between doses of aminoglycosides have changed in neonates during recent years. Initially, the dose of gentamicin was $2.5 \mathrm{mg} / \mathrm{kg}$ every $12 \mathrm{~h}$ [70]. This dosage yields peak concentration $<5 \mu \mathrm{g} / \mathrm{kg}$ and trough concentration $>2 \mu \mathrm{g} / \mathrm{mL}$ in some patients. Increasing the gentamicin dose to $4-5 \mu \mathrm{g} / \mathrm{mL}$ once-daily, the peak and trough concentration of gentamicin ranged between 5 and $12 \mu \mathrm{g} / \mathrm{mL}$. Increasing the gentamicin dose to $5 \mu \mathrm{g} / \mathrm{mL}$ and extending the interval between doses to $36-48 \mathrm{~h}$ the gentamicin peak and trough concentrations ranged between $<12$ and $<2 \mu \mathrm{g} / \mathrm{mL}$, respectively [75-79]. This consideration also applies to tobramycin and netilmicin.

Gestational age and postnatal age have an important effect on $\mathrm{Cl}$ and consequently on $\mathrm{t}_{1 / 2}$ of penicillins $[10,14,15,18,20,22,23,29]$, cephalosporins $[33,38,42,43,45,57,60,63]$ and aminoglycosides [78,79,85,86,107]. Thus, gestational and postnatal ages are factors generating interindividual variability in the pharmacokinetics of penicillins, cephalosporins and aminoglycosides. Other factors that contribute to the interindividual variability in the pharmacokinetics of these antibiotics are malnutrition, disease and genetics. These factors coexist, and it is difficult to distinguish them among the different factors. Monitoring antibiotic serum concentration, particularly aminoglycosides, is necessary, especially in critical patients such as the preterm infants. Penicillins, cephalosporins and aminoglycosides are fairly water soluble and are mainly eliminated by renal route. The renal excretory function increases with gestational age as the GFR is lower in the premature than in term neonates $[98,108]$ and increases with the postnatal age $[46,49]$. $\mathrm{Cl}$ of cefotaxime is $2-3$ folds higher in term than preterm infants [34,35]. Gentamicin $\mathrm{Cl}$ correlates $(r=0.99)$ with creatinine $\mathrm{Cl}$ [109] and gentamicin $\mathrm{t}_{1 / 2}$ correlates $(\mathrm{r}=0.78)$ with plasma creatinine concentration [106]. $\mathrm{Cl}$ of ceftazidime correlated with the reciprocal of the serum concentration of creatinine $(r=0.72$; $\mathrm{p}<0.001$ ) suggesting that creatinine can interfere with the renal clearance of ceftazidime.

From a pharmacokinetic point of view, penicillins, cephalosporins and aminoglycosides are rapidly eliminated and their $t_{1 / 2}$ ranges from 1.4 to $6.7 \mathrm{~h}$ for penicillins and to $16.2 \mathrm{~h}$ for ceftriaxone. In the preterm, $t_{1 / 2}$ is longer than in full-term infants as these antibiotics are mainly eliminated by renal route and the excretory renal function increases with prenatal and postnatal development. This has been observed for azlocillin [24], ticarcillin [29], cefotaxime [35], ceftazidime [42], cefoperazone [59], gentamicin [81] and amikacin [98]. Cl has a reverse trend, it is lower in preterm than in full-term infants.

The present article is a comprehensive and updated review and summarises the pharmacokinetics of penicillins, cephalosporins and aminoglycosides in neonates in one article making it a useful tool in the hands of physicians. Paap and Nahata published a review on the clinical pharmacokinetics of antibacterial drugs in neonates in 1990 [7]. Although this article is a comprehensive review, the rapid progress of the pharmacology soon made it obsolete. In 1995, Lipuma et al. [110] published a review on the antibacterial agents in paediatrics, and in the same year, Sato [101] published an article on the pharmacokinetics of antibiotics in neonates. Recently, two reviews focused only on the pharmacokinetics of penicillins [112] or aminoglycosides [113] in neonates, and at present, there is not 
an updated review on the pharmacokinetics of cephalosporins in the neonate. The previous reviews were descriptive and do not give detailed information on the kinetic parameters of the various antibiotics. The present review adds in comparison with previous reviews an analysis of the kinetic parameters for penicillins, cephalosporins and aminoglycosides in the neonate. In addition, this review provides an analysis of the kinetics of cephalosporins in the neonate filling a space in the literature.

Several factors influence the pharmacokinetics of penicillins, cephalosporins and aminoglycosides in the neonates. It is difficult to predict the pharmacokinetic behaviour of these drugs as many factors influence their disposition. The pharmacokinetics of these antibiotics should be investigated in order to ensure that the doses recommended for the treatment of sepsis are evidence based.

\section{Acknowledgements}

This work has been supported by the Ministry of the University and Scientific and Technological Research, Rome, Italy.

\section{References}

1. Bonati, M. Early neonatal drug utilisation in preterm newborns in neonatal intensive care units: Italian collaborative group on preterm delivery. Dev. Pharmacol. Ther. 1988, 11, 1-7.

2. Eriksson, M. Neonatal septicemia. Acta Paediatr. Scand. 1983, 72, 1-8.

3. Schelonka, R.L.; Infante, A.J. Neonatal immunology. Semin. Perinatol. 1998, 22, 2-14.

4. Friis-Hansen, B. Body water compartments in children: changes during growth and related changes in body composition. Pediatrics 1961, 28, 169-181.

5. Morselli, P.L.; Franco-Morselli, R.; Bossi, L. Clinical pharmacokinetics in newborns and infants. Age-related differences and therapeutic implications. Clin. Pharmacokinet. 1980, 5, 485-527.

6. HeimLer, R.; Doumas, B.T.; Jendrzejczak, B.M.; Nemeth, P.B.; Hoffman, R.G.; Nelin, L.D. Relationship between nutrition, weight change, and fluid compartments in preterm infants during the first week of life. J. Pediatr. 1993, 122, 110-114.

7. Paap, C.M.; Nahata, M.C. Clinical pharmacokinetics of antibacterial drugs in neonates. Clin. Pharmacokinet. 1990, 19, 280-318.

8. Young, T.E.; Mangum, B. The Antibiotics. Neofax: A Manual of Drugs Used in Neonatal Care, $20^{\text {th }}$ ed; Thomson Healthcare: Montvale, NJ, USA, 2007; pp. 2-77.

9. McCracken, G.H., Jr.; Ginsberg, C.; Chrane, D.F.; Thomas, M.L.; Horton, L.J. Clinical pharmacology of penicillins in newborn infants. J. Pediatr. 1973, 82, 692-698.

10. Metsvaht, T.; Oselin, K.; Ilmoja, M.L.; Anier, K.; Lutsar, I. Pharmacokinetics of penicillin G in very-low-birth-weight neonates. Antimicrob. Agents Chemother. 2007, 51, 1995-2000.

11. Muller, A.E.; DeJongh, J.; Bult, Y. Pharmacokinetics of penicillin G in infants with a gestational age of less than 32 weeks. Antimicrob. Agents Chemother. 2007, 51, 3720-3725.

12. Yoshioka, H.; Takimoto, M.; Riley, H.D., Jr. Pharmacokinetics of ampicillin in the new born infant. J. Infect. Dis. 1974, 129, 461-464.

13. Sutton, A.M.; Turner, T.L.; Cockburn, F.; McAllister, T.A. Pharmacokinetic study of sulbactam and ampicillin administered concomitantly by intraarterial or intravenous infusion in the newborn. Rev. Infect. Dis. 1986, 8 (Suppl. 5), S518-S522. 
14. Kaplan, J.M.; McCracken, G.H., Jr.; Horton, L.J.; Thomas, M.J.; Davis, N. Pharmacologic studies in neonates given large dosages of ampicillin. J. Pediatr. 1974, 84, 571-577.

15. Axline, G.S.; Yaffe, S.J.; Simon, H.F. Clinical pharmacology on antimicrobials in premature infants II. Ampicillin, Methicillin, oxacillin neomycin and colistin. Pediatrics 1967, 39, 97-107.

16. Charles, B.G.; Preechagoon, Y.; Lee, T.C.; Steer, P.A.; Flenady, V.J.; Debuse N. Population pharmacokinetics of intravenous amoxicillin in very low birth weight infants. J. Pharm. Sci. 1997, 86, 1288-1292.

17. Huisman-de Boer, J.J.; van den Anker, J.N.; Vogel, M.; Goessens, W.H.F.; Schoemarker, R.C.; de Groot, R. Amoxicillin pharmacokinetics in preterm infants with gestational ages of less than 32 weeks. Antimicrob. Agents Chemother. 1995, 39, 431-434.

18. Pullen J.; Stolk, L.M.; Nieman, F.H.; Degraeuwe, P.L.; van Tiel, F.H.; Zimmermann L.J. Population pharmacokinetics and dosing of amoxicillin in (pre)term neonates. Ther. Drug Monit. 2006, 28, 226-231.

19. Adrianzén Vargas, M.R.; Danton, M.H.; Javaid, S.M.; Gray, J.; Tobin, C.; Brawn, W.J.; Barron, D.J. Pharmacokinetics of intravenous flucloxacillin and amoxicillin in neonatal and infant cardiopulmonary bypass surgery. Eur. J. Cardiothorac. Surg. 2004, 25, 256-260.

20. Pullen, J.; Driessen, M.; Stolk, L.M.L. Amoxicillin pharmacokinwtics in (preterm) infants aged 10 to 52 days: Effect of postnatal age. Ther. Drug Monit. 2007, 29, 376-380.

21. Weingartner, L.; Sitka, U.; Patsch, R.; Richter, I. Experience with amoxicillin in neonates and premature babies. Int. J. Clin. Pharmacol. Biopharm. 1977, 15, 184-188.

22. Pullen, J.; de Rozario, L.; Stold, L.M.; Degraeuwe, P.L.; van Tiel, F.H.; Zimmermann, L.J. Population pharmacokinetic and dosing of flucloxacillin in preterm and term neonates. Ther. Drug Monit. 2006, 28, 351-358.

23. Herngren, L.; Ehrnebo, M.; Broberger, U. Pharmacokinetics of free and total flucloxacillin in newborn infants. Eur. J. Clin. Pharmacol. 1987, 32, 403-409.

24. Sitka, U.; Weingarterner, L.; Patsch, R.; Richter, I. Pharmacokinetics of azlocillin in neonates. Chemotherapy 1980, 26, 171-176.

25. Heimann, G. Pharmacokinetics and clinical aspects of azlocillin in paediatrics. J. Antimicrob. Chemother. 1983, 11, 127-135.

26. Janicke, D.M.; Rubio, T.T.; Wirth, F.H.; Karotkin, E.H.; Jusko, W.J. Developmental pharmacokinetics of mezlocillin in newborn infants. J. Pediatr. 1984, 104, 773-781.

27. Odio, C.; Threlkeld, N.; Thomas, M.L.; McCraken, G.H., Jr. Pharmacokinetic properties of mezlocillin in newborn infants. Antimicrob. Agents Chemother. 1984, 25, 556-559.

28. Fayed, S.B.; Sutton, A.M.; Turner, T.L.; McAllister, T.A. The prophylactic use of ticarcillin/clavulanate in the neonate. J. Antimicrob. Chemother. 1987,19,113-118.

29. Fricke, G.; Doerck, M.; Hafner, D.; Horton, R.; Kresken, M. The pharmacokinetics of ticarcillin/clavulanate acid in neonates. J. Anticrob. Chemother. 1989, 24, 111-120.

30. Burstein, A.H.; Wyble, L.E.; Gal, P.; Diaz, P.R.; Ransom, J.L.; Carlos, R.Q.; Forrest, A. Ticarcillin-clavulanic acid pharmacokinetics in preterm neonates with presumed sepsis. Antimicrob. Agents Chemother. 1994, 38, 2024-2028. 
31. Deguchi, Y.; Koshida, R.; Nakashima, E.; Watanabe, R.; Taniguchi, N.; Ichimura, F.; Tsuji, A. Interindividual changes in volume of distribution of cefazolin in newborn infants and its prediction based on physiological pharmacokinetic concepts. J. Pharm. Sci. 1988, 77, 674-678.

32. Regazzi, M.B.; Chirico, G.; Cristiani, D.; Rondini, G.; Rondanelli, R. Cefoxitin in newborns. A clinical and pharmacokinetics study. Eur. J. Clin. Pharmacol. 1983, 25, 507-509.

33. Relund, M.; Pettay, O. Pharmacokinetics and clinical efficacy of cefuroxime in the newborn period. Proc. Roy. Soc. Med. 1977, 70, 179-182.

34. Kafetzis, D.A.; Brater, D.C.; Kapiki, A.N.; Papas, C.V.; Dellagrammatics, H.; Papadotos, C.J. Treatment of severe neonatal infections with cefotaxime. Efficacy and pharmacokinetics. J. Pediatr. 1982, 100, 483-489.

35. McCracken, G.H.; Threlkeld, N.A.; Thomas, M.L. Pharmacokinetics of cefotaxime in newborn infants. Antimicrob. Agents Chemother. 1982, 21, 683-684.

36. Aujard, Y.; Brion, F.; Jacqz-Aigrain, E.; Kasse, M.C..; Chretien, P.; Criqui, C.; Mathieu, H. Pharmacokinetics of cefotaxime and desacetylcefotaxime in the newborn. Diagn. Microbiol. Infect. Dis. 1989, 12, 87-91.

37. Baird-Lambert, J.; Doyle, P.E.; Cvejc, M.; Buchanan, N. Pharmacokinetics of cefotaxime in neonates. J. Antimicrob. Chemother. 1984, 13, 471-477.

38. Gouyon, J.B.; Pechinot, A.; Safran, C.; Chretien, P.; Sandre, D.; Kazmierczak, A. Pharmacokinetics of cefotaxime in preterm infants. Dev. Pharmacol. Ther. 1990, 14, 29-34.

39. Kearns, G.L.; Jacobs, R.F.; Thomas, B.R.; Darville, T.L.; Trang, J.M. Cefotaxime and desacetylcefotaxime pharmacokinetics in very low birth weight neonates. J. Pediatr. 1989, 114, 461-467.

40. Crooks, J.; White, L.O.; Burville, L.J.; Speidel, B.D.; Reeves, D.S. Pharmacokinetics of cefotaxime and desacetyl-cefot7axime in neonates. J. Antimicrob. Chemother. 1984, 14, 97-101.

41. Boccazzi, A.; Rizzo, M.; Caccamo, M.L.; Assael, B.M. Comparison of the concentrations of ceftazidime in the serum of newborns infants after intravenous and intramuscular administration. Antimicrob. Agents Chemother. 1983, 24, 955-956.

42. McCracken, G.H., Jr.; Threlkeld, N.; Thomas, M.L. Pharmacokinetics of ceftazidime in newborn infants. Antimicrob. Agents Chemother. 1984, 26, 583-584.

43. Mulhall, A.; de Louvois, J. The pharmacokinetics and safety of ceftazidime in the neonate. J. Antimicrob. Chemoter. 1985, 15, 97-103.

44. van den Anker, J.N.; Schoemaker, R.C.; Hop, W.C.; van der Heijden, B,J.; Weber, A.; Sauer, P.J.; Neijens, H.J.; de Groot, R. Ceftazidime pharmacokinetics in preterm infants: effects of renal function and gestational age. Clin. Pharmacol. Ther. 1995, 58, 650-659.

45. van den Anker, J.N.; Hop, W.C.; Schoemaker, R.C.; van der Heijden, B.J.; Neijens, H.J.; de Groot, R. Ceftazidime pharmacokinetics in preterm infants: effect of postnatal age and postnatal exposure to indomethacin. Br. J. Clin. Pharmacol. 1995, 40, 439-443.

46. van den Anker, J.N.; Schoemaker, R.C.; van der Heijden, B.J.; Broerse, H.M.; Neijens, H.J.; de Groot, R. Once-daily versus twice-daily administration of ceftazidime in the preterm infant. Antimicrob. Agents Chemother. 1995c, 39, 2048-2050.

47. Gentry, L.O. Antimicrobial activity, pharmacokinetics, therapeutic indications and adverse reactions of ceftazidime. Pharmacotherapy 1985, 5, 254-267. 
48. Neu, H.C. Pathophysiologic basis for the use of third-generation cephalosporins. Am. J. Med. 1990, 88 (Suppl. 4A), 3S-11S.

49. Martin, E.; Koup, J.R.; Paravicini, U.; Stoeckel, K. Pharmacokinetics of ceftriaxone in neonates and infants with meningitis. J. Pediatr. 1984, 105, 475-481.

50. Mulhall, A.; de Louvois, J.; James, J. Pharmacokinetics and safety of ceftriaxone in the neonate. Eur. J. Pediatr. 1985, 144, 379-382.

51. Steele, R.W.; Eyre, L.B.; Bradsher, R.W.; Weinfeld, R.E.; Patel, I.H.; Spicehandler, J. Pharmacokinetics of ceftriaxone in pediatric patients with meningitis. Antimicrob. Agents Chemother. 1983, 23, 191-194.

52. Martin, E.; Fanconi, S.; Kälin, P.; Zwingelstein, C.; Crevoisier. C.; Ruch, W.; Brodersen, R. Ceftriaxone-bilirubin-albumin interactions in the neonate: an in vivo study. Eur. J. Pediatr. 1993, 152, 530-534.

53. Gulian, J.M.; Gonard, V.; Dalmasso, C.; Palix, C. Bilirubin displacement by ceftriaxone in neonates: evaluation by determination of 'free' bilirubin and erythrocyte-bound bilirubin. J. Antimicrob. Chemother. 1987, 19, 823-829.

54. Steadman, E.; Raisch, D.W.; Bennett, C.L.; Esterly, J.S.; Becker, T.; Postelnick, M.; McKoy, J.M.; Trifilio, S.; Yarnold, P.R.; Scheetz, M.H. Evaluation of a potential clinical interaction between ceftriaxone and calcium. Antimicrob. Agents Chemother. 2010, 54,1534-1540.

55. Park, H.Z.; Lee, S.P.; Schy, A.L. Ceftriaxone-associated gallbladder sludge. Identification of calcium-ceftriaxone salt as a major component of gallbladder precipitate. Gastroenterology 1991, 100, 1665-1670.

56. Varghese, M.; Khan, A.J.; Kumar, K.; Rosenfeld, W.; Schaeffer, H.A.; Evans, H.E. Pharmacokinetic evaluation of cefoperazone in infants. Antimicrob. Agents Chemother. 1985, 28, 149-150.

57. Bosso, J.A.; Chan, G.M.; Matsen, J.M. Cefoperazone pharmacokinetics in preterm infants. Antimicrob. Agents Chemother. 1983, 23, 413-415.

58. Philips, J.B., 3rd; Braune, K.; Ravis, W.; Cassady, G.; Dillon, H. Pharmacokinetics of cefoperazone in newborn infants. Pediatr. Pharmacol. 1984, 4, 193-197.

59. Rosenfeld, W.N.; Evans, H.E.; Batheja, R.; Jhaveri, R.C.; Vohra, K.; Khan, A.J. Pharmacokinetics of cefoperazone in full-term and premature neonates. Antimicrob. Agents Chemother. 1983, 23, 866-869.

60. Cutler, R.E.; Blair, A.D.; Burgess, E.D.; Parks, D. Pharmacokinetics of ceftizoxime. J. Antimicrob. Chemother. 1982, 91-97.

51. Karna, P.; Lee, C.; Kumar, A.; Dyke, J.; Gooch, W. M., 3rd. Population pharmacokinetics of ceftizoxime in premature newborns. Dev. Pharmacol. Ther. 1993, 20, 135-143.

62. Capparelli, E.; Hochwald, C.; Rasmussen, M.; Parham, A.; Bradley, J.; Moya, F. Population pharmacokinetics of cefepime in the neonate. Antimicrob. Agents Chemother. 2005, 49, 2760-2766.

63. Reed, M.D.; Yamashita, T.S.; Knupp, C.K.; Veazey, J.M. Jr.; Blumer, J.L. Pharmacokinetics of intravenously and intramuscularly administered cefepime in infants and children. Antimicrob. Agents Chemother. 1997, 41, 1783-1787. 
64. Lima-Rogel, V.; Medina-Rojas, E.L.; Del Carmen Milán-Segovia, R.; Noyola, D.E.; NietoAguirre, K.; López-Delarosa, A.; Romano-Moreno, S. Population pharmacokinetics of cefepime in neonates with severe nosocomial infection. J. Clin. Pharmacol. Ther. 2008, 33, 295-306.

65. Chambers, H.F. The Aminoglycosides. In Goodman \& Gilman's the Pharmacologic Basis of Therapeutics, 11th ed.; Brunton, L.L., Lazo, J.S., Parker, K.L., Eds.; McGraw Hill: Columbus, OH, USA, 2006; pp. 1155-1171.

66. Matz, G.J. Aminoglycoside cochlear ototoxicity. Otoryngol. Clin. North Am. 1993, 5, 705-712.

67. Andronikou, S.; Giapros, V.I.; Cholevas, V.I.; Popadopoulou, Z.L. Effect of aminoglycosides therapy on renal function in full term infants. Pediatr. Nephrol. 1996, 10, 766-768.

68. Swan, S.K. Aminoglycoside nephrotoxicity. Semin. Nephrol. 1997, 17, 27-33.

69. Kovarik, J.M.; Hoepelman, I.M.; Verhoef, J. Once-daily aminoglycoside administration: new strategies for old drug. Eur. J. Clin. Microb. Infect. Dis. 1989, 8, 764-769.

70. Hindmarsh, K.W.; Nation, R.L.; Williams, G.L.; John, E.; French, J.N. Pharmacokinetics of gentamicin in very low birth weight preterm infants. Eur. J. Clin. Pharmacol. 1983, 24, 649-953.

71. Rao, E.M.; Ahmed, M.; Hagan, R. One dose per day compared to multiple doses per day of gentamicin for treatment of suspected or proven sepsis in neonates. Cochrane Database Syst. Rev. 2006, 25, CD005091.

72. Miron, D. Once daily dosing of gentamicin in infants and children. Pediatr. Infect. Dis. J. 2001, 20, 1169-1173.

73. Rastogi, A.; Agarwal, G.; Pyati, S.; Pilles R. Comparison of two gentamicin dosing schedules in very low birth weight infants. Pediatr. Infect. Dis. J. 2002, 21, 234-240.

74. Avent, M.L.; Kinney, J.S.; Istre, G.R. Whitfield, J.M. Gentamicin and tobramycin in neonates: Comparison of a new extended dosing interval regimen with a traditional multiple daily dosing regimen. Am. J. Perinatol. 2002, 19, 413-419.

75. Lanao, J.M.; Calvo, M.V.; Mesa, J.A; Martin-Suarez, A.; Carbajosa, M.T.; Miguelez, F.; Dominguex-Gill, A. Pharmacokinetic basis for the use of extended interval dosage regimens of gentamicin in neonates. J. Antimicrob. Chemother. 2004, 54, 193-198.

76. Mercado, M.C.K.; Brodsky, N.L.; McGuire, M.K.; Hurt, H. Extended interval dosing of gentamicin in preterm infants. Am. J. Perinatol. 2004, 21, 73-77.

77. Begg, E.J.; Vella-Brincat, J.W.; Robertshawe, B.; McMurtrie, M.J.; Kirkpatrick, C.M.; Darlow, B. Eight years' experience of an extended-interval dosing protocol for gentamicin in neonates. J. Antimicrob. Chemother. 2009, 63, 1043-1049.

78. Hossain, M.M.; Chowdhury, N.A.; Shirin, M.; Saha, S.K.; Miller-Bell, M.; Edwards, D.; Aranda, J.; Coffey, P.; Darmstadt, G.L. Simplified dosing of gentamicin for treatment of sepsis in Bangladeshi neonates. J. Health Popul. Nutr. 2009, 27, 640-645.

79. Chuck, S.K.; Raber, S.R.; Rodvold, K.A.; Areff, D. National survey of extended-interval aminoglycoside dosing. Clin. Infect. Dis. 2000, 30, 433-439.

80. Maglio, D.; Nightingale, C.H.; Nicolau, D.P. Extended interval aminoglycoside dosing: from concept to clinic. Int. J. Antimicrob. Agents 2002, 19, 341-348.

81. Di Cenzo, R.; Forrest, A.; Slish, J.C.; Cole, C.; Guillet, R.A. Gentamicin pharmacokinetic population model and once-daily dosing algorithm for neonates. Pharmacotherapy 2003, 32, 585-591. 
82. Krishnan, L.; George, S.A. Gentamicin therapy in preterms: a comparison of two dosage regimens. Indian Pediatr. 1977, 34, 1075-1080.

83. de Alba Romero, C.; Gomez Castillo, E.; Manzanares Secades, C.; Rodriguez Lopez, J.; Arreaza Lopez, J.; Saenz Valiente, P. Once-daily gentamicin dosing in neonates. Pediatr. Infect. Dis. J. 1998, 17, 1169-1171.

84. Agarwal, G.; Rastogi, A.; Pyati, S.; Wilks, A.; Pildes, R.S. Comparison of once-daily versus twice-daily gentamicin dosing regimens in infant $\geq 2500$ g. J. Perinatol. 2002, 22, 268-274.

85. Gosden, P.E.; Bedford, K.A.; Dixon, J.J.; Speidel, B.D.; Leaf, A.A.; Macgowan, A.P. Pharmacokinetics of once-a day netilmicin $[4.5 \mathrm{mg} / \mathrm{kg}]$ in neonates. J. Chemother. 2001, 13, 270-276.

86. Ettlinger, J.J.; Bedford, K.A.; Lovering, A.M.; Reeves, D.S.; Speidel, B.D.; MacGowan, A.P. Pharmacokinetics of once-a-day netilmicin $[6 \mathrm{mg} / \mathrm{kg}]$ in neonates. J. Antimicrob. Chemother. 1996, 38, 499-505.

87. Siegel, J.D.; McCracken, G.H. Jr; Thomas, M.L.; Threlkeld, N. Pharmacokinetic properties of netilmicin in newborn infants. Antimicrob. Agents Chemother. 1979, 15, 246-253.

88. Klingenberg, C.; Smabrekke, L.; Lier, T.; Flaegstad, T. Validation of a simplified netilmicin dosage regimen in infants. Scand. J. Infect. Dis. 2004, 36, 474-479.

89. Kuhn, R.J.; Nahata, M.C.; Powell, D.A.; Bickers, R.G. Pharmacokinetics of Netilmicin in premature infants. Eur. J. Clin. Pharmacol. 1986, 29, 635-637.

90. Granati, A.; Assael, B.M.; Chung, M.; Montini, C.; Parini, R.; Pallazzon, P.; Gagliardi, L.; Radwanski, E.; Rubaltelli, F.F. Clinical pharmacology of netilmicin in preterm and term newborn infants. J. Pediatr. 1985, 106, 664-669.

91. Sherwin, C.M.; Svahn, S.; Van der Linden, A.; Broadbent, R.S.; Medlicott, N.J.; Reith, D.M. Individualised dosing of amikacin in neonates: a pharmacokinetic/pharmacodynamic analysis. J. Clin. Pharmacol. 2009, 65, 705-13.

92. Nahata, M.C.; Powel, D.A.; Durrel, D.E.; Miller, M.A. Tobramycin pharmacokinetics in very low birth weight infant. Br. J. Clin. Pharmacol. 1986, 21, 325-327.

93. Nahata, M.C.; Durrel, D.E.; Miller, M.A. Tobramycin pharmacokinetics in prematures identical twins during newborn period. Dev. Pharmacol. Ther. 1986, 9, 178-182.

94. Yoshioka, H.; Takimoto, M.; Fujita, K.; Maruyama, S. Pharmacokinetics of tobramycin in the newborn. Infection 1979, 7, 180-182.

95. de Hoog, M.; Mouton, J.W.; Schormaker, R.C.; Verduin, C.M.; van den Anker, J.N. Extendedinterval dosing of tobramycin in neonates: implications for therapeutic drug monitoring. Clin. Pharmacol. Ther. 2002, 71, 349-58.

96. de Hoog, M.; Schoemaker, R.C.; van den Anker, J.N.; Vinks, A.A. NONMEM and NPEM2 population modeling: a comparison using tobramycin data in neonates. Ther. Drug Monit. 2002b; 24, 359-365

97. Sardemann, H.; Colding, H.; Hendel, J.; Kampmann, J.P.; Hvidberg, E,F.; Vejisgaard, R. Kinetics and dose calculations of amikacin in the newborn. Clin. Pharmacol. Ther. 1976, 20, 59-66.

98. Padovani, E.M.; Pistolesi, C.; Fanos, V.; Messori, A.; Martini, N. Pharmacokinetics of amikacin in neonates. Dev. Pharmacol. Ther. 1993, 20, 167-173. 
99. Assael, B.M.; Parini, R.; Rusconi, F.; Cavanna, G. Influence of intrauterine maturation on the pharmacokinetics of amikacin in the neonatal period. Pediat. Res. 1982, 16, 810-815.

100. Kenyon, C.F.; Knoppert, D.C.; Lee, S.K.; Wandenberghe, H.M.; Chance, G.W. Amikacin pharmacokinetics and suggested dosage modifications for preterm infant. Antimicrob. Agents Chemother. 1990, 34, 265-268.

101. Tréluyer, J.M.; Merlé, Y.; Tonnelier, S.; Rey E.; Pons, G. Nonparametric population pharmacokinetics analysis of amikacin in neonates, infants and children. Antimictob. Agents Chemother. 2002, 46, 1381-1387.

102. Wang, J.; Liang, W.-Q.; Wu, J.J.; Pan, C.M. Population pharmacokinetics analysis of amikacin and validation on neonates using Monte Carlo method. Acta Pharmacol. Sin. 2000, 21, 954-960.

103. Langhendries, J.P.; Battisti, O.; Bertrand, J.M.; Francois, A.; Darmiont, J.; Ibrahim, S.; Tulkens, P.M.; Bernard, A.; Buchet, J.P.; Scalais, E. Once-a-day administration of amikacin in neonates: assessment of nephrotoxicity and ototoxicity. Dev. Pharmacol. Ther. 1993, 30, 220-230.

104. Sherwin, C.M.; Broadbent, R.S.; Medlicott, N.J.; Reith, D.M. Individualising netilmicin dosing in neonates. Eur. J. Clin. Pharmacol. 2008, 64, 1201-1208.

105. Allegaert, K.; Cossey, V.; Langhendries, J.P.; Nauleers, G.; Vanhole, C.; Devlieger, H.; Van Overmeire, A. Effects of co-administration of ibuprofen-lysine on the pharmacokinetics of amikacin in preterm infants during the first days of life. Biol. Neonate 2004, 86, 207-211.

106. Brion, L.P.; Fleischman, A.R.; Schwartz, G.J. Gentamicin interval in newborn infants as determined by renal function and postconceptional age. Pediatr. Nephrol. 1991, 5, 675-679.

107. Nielsen, E.I.; Sandström, M.; Honoré, P.H.; Ewald, U.; Friberg, L.E. Developmental pharmacokinetics of gentamicin in preterm and term neonates: population modelling of a prospective study. Clin. Pharmacokinet. 2009, 48, 253-63.

108. Allegaert, K.; Anderson, B.J.; van den Anker, J.N.; Vanhaesebrouck, S.; de Zegher, F. Renal drug clearance in preterm neonates: relation to prenatal growth. Ther. Drug Monit. 2007, 29, 284-291.

109. Kildoo, C.; Modanlou, H.D.; Komatsu, G.; Harralson, A.; Hodding, J. Developmental pattern of gentamicin kinetics in very low birth weight (VLBW) sick infants. Dev. Pharmacol. Ther. 1984, 7, 345-356.

110. LiPuma, J.J.; Stull, T.L. Antibacterial agents in pediatrics. Infect. Dis. Clin. North Am. 1995, 9, 561-574.

111. Sato, Y. Pharmacokinetics of antibiotics in neonates. Acta. Paediatr. Jpn. 1997, 39, 124-131.

112. Pacifici, G.M.; Labatia, J.; Mulla, H; Choonara, J. Clinical pharmacokinetics of penicillins in the neonate: a review of the literature. Eur. J. Clin. Pharmacol. 2009, 65, 191-198.

113. Pacifici, G.M. Clinical pharmacokinetics of aminoglycosides in the neonate: a review. Eur. J. Clin. Pharmacol. 2009, 65, 419-427.

(C) 2010 by the authors; licensee MDPI, Basel, Switzerland. This article is an Open Access article distributed under the terms and conditions of the Creative Commons Attribution license (http://creativecommons.org/licenses/by/3.0/). 